\title{
Micro-grid Design and Cost Optimization using Modelica
}

\author{
Natesa MacRae ${ }^{1} \quad$ John Batteh $^{2} \quad$ Stéphane Velut $^{3} \quad$ William Skrivan $^{1}$ \\ Imran Khan $^{1}$ Darren Jang ${ }^{1}$ \\ ${ }^{1}$ National Research Council Canada, Canada, \{Natesa.MacRae, Imran.Khan, William.Skrivan, \\ Darren.Jang @ nnrc-cnrc.gc.ca \\ ${ }^{2}$ Modelon Inc., USA, $\{$ john. batteh $\}$ @modelon. com \\ ${ }^{3}$ Modelon AB, Sweden, \{stephane. velut\} @modelon. com
}

\begin{abstract}
This paper describes the modeling capability for the National Research Council of Canada (NRC) MicroGrid Testing and Training Facility, which will be used to advance energy generation and storage technologies and optimize integrated system operations for a variety of micro-grid applications. First, an integrated system model was assembled using the Microgrid Modelica library, developed by Modelon. Next, three use cases were defined based on the Whale Cove, Nunavut microgrid operating in: 'island mode' without renewables (present mode), island mode with renewables, and gridconnected mode. Finally, various design, environmental, and economic analyses and optimizations were performed. Through these analyses, it was shown that each parameter domain could be successfully assessed using this modeling framework, demonstrating the flexibility of the modeling platform and the potential for the physical test facility to support in-depth analyses and optimizations for different microgrid configurations, technologies, and applications.
\end{abstract}

Keywords: Micro-grid, remote area, grid-connected, island mode, distributed energy resources, renewables, energy storage, solar photovoltaics, combined heat and power generation, model, energy balance, optimization.

\section{Introduction}

Canada has an estimated 280 remote communities and commercial sites where power is predominantly supplied by standalone diesel generators (NRCan 1, 2018). Because of their high reliance on diesel, the remote micro-grids supplying power to these communities are expensive to operate, generate significant emissions, and can face substantial risk if critical supply shipments of diesel are disrupted. Introducing renewable energy sources provides an opportunity to increase energy security and reduce both operating costs and emissions; however, due to the variable energy output of renewables such as wind and solar, this can add complexity for maintaining the control and stability of the integrated electrical system. Optimizing the size of renewable energy installations can also be a challenge in northern communities due to seasonal variations, where solar generators produce less power in the winter when the demand for energy is the highest, and more power in the summer when the demand is low (sometimes resulting in curtailment).

Presently, a substantial amount of research is being directed at analyzing new and innovative micro-grid configurations and technologies. This includes evaluating micro-grids operating as a stand-alone system, as a building block in a flexible micro-grid 'network' consisting of various distributed energy resources and consumer loads, or as backup for those connected to a centralized grid. Particularly, in the case of micro-grid / grid integration, challenges associated with switching between grid-connected and island modes, as well as reliability, power quality, and protection requirements, have received limited investigation (Ackeby, 2017).

In all cases, these new and emerging technologies and micro-grid configurations will need to be successfully demonstrated to ensure that they are safe, reliable, and able to meet the strict performance and operational requirements of the communities or applications they are intended to support. To reduce the risks associated with initial deployment, it will also be essential to identify operating, maintenance, and / or repair challenges before these systems are delivered to remote communities, where issues will be more costly and challenging to resolve. Having the ability to integrate and operate these systems in a safe, controlled facility that can simulate both nominal and off-nominal operating conditions as well as facilitate operator / technician training (from suppliers and distributors to system integrators and end users) would offer the highest potential for successful integration. For this reason, the NRC is building a physical Micro-Grid Testing and Training Facility as well as a virtual modeling / simulation capability using the Microgrid Modelica library developed by Modelon. Although this initial study focused primarily on integrated system design and operating strategies that reduce costs, fuel consumption, and greenhouse gas (GHG) emissions, future modeling efforts will include the use of Modelon's Electric Power Modelica library (Modelon, 2019) for control, stability, and transient analysis. 


\section{Background}

\subsection{Micro-Grid Facility}

The NRC Micro-Grid Testing and Training Facility has been designed to facilitate the analysis of the systems and technologies that support remote community microgrids, grid-connected stand-by power plants, and offgrid residential, military, or commercial sites. Once construction is complete, this facility will allow the flexible integration of a range of power generation and storage technologies into an existing power network to support their assessment under a variety of real-world conditions. Testing capabilities will include evaluating different power / energy configurations, simulating transient conditions and events, supporting micro-grid control system design and optimization, and performing accelerated lifetime testing to optimize the reliability of pilot-scale systems and their components. Results of this testing will support the understanding, advancement, and deployment of micro-grid technologies, interfaces, and configurations, and be used to inform new policies and safety regulations. The facility will also offer a reduced-risk training environment for end-users to familiarize themselves with the operation and maintenance of new systems and to provide practical feedback to technology developers.

The facility will consist of a unique set of distributed energy resources including a:

- Biomass-fueled Combined Heat and Power (CHP) generator, $\sim 40 \mathrm{~kW}$ of electricity $\left(\mathrm{kW}_{\mathrm{e}}\right)$ and $\sim 100$ $\mathrm{kW}$ of heat $\left(\mathrm{kW}_{\mathrm{th}}\right)$

- Flat-panel building-integrated solar photovoltaic (PV) system $(\sim 10 \mathrm{~kW})$

- Concentrating mirror Photovoltaic (CPV) system $(\sim 10 \mathrm{~kW})$

- Diesel generator

- Energy storage system

The facility will also have the ability to operate in gridconnected or island mode (i.e., as an isolated microgrid). (NRC, 2019).

\subsubsection{Biomass Combined Heat and Power}

The biomass CHP generator, shown in Figure 1, uses renewable biomass as an alternative to fossil fuels to generate both heat and power. The unit gasifies wood chips to produce a synthetic gas ("syngas"), which is then cooled and filtered prior to fueling a conventional spark-ignition internal combustion engine. The engine is coupled to an electric generator to produce $\sim 40 \mathrm{~kW}_{\mathrm{e}}$, as well as $\sim 100 \mathrm{~kW}_{\text {th }}$ as warm water (Volter, 2019).

Biomass can be viewed as carbon neutral, in that the $\mathrm{CO}_{2}$ the biomass removes from its environment during growth is equal to the $\mathrm{CO}_{2}$ released during its combustion, resulting in 'net-zero' carbon emissions; however, because carbon storage in wood products only occurs gradually over a long period of time, compared with the rapid release of $\mathrm{CO}_{2}$ that occurs when these feedstocks are processed, the environmental benefits of this approach are still the subject of much debate (Harvey, 2018). Typically, only low value biomass feedstocks are used as fuel for these generators (e.g., wood chips or pellets generated from forestry waste streams).

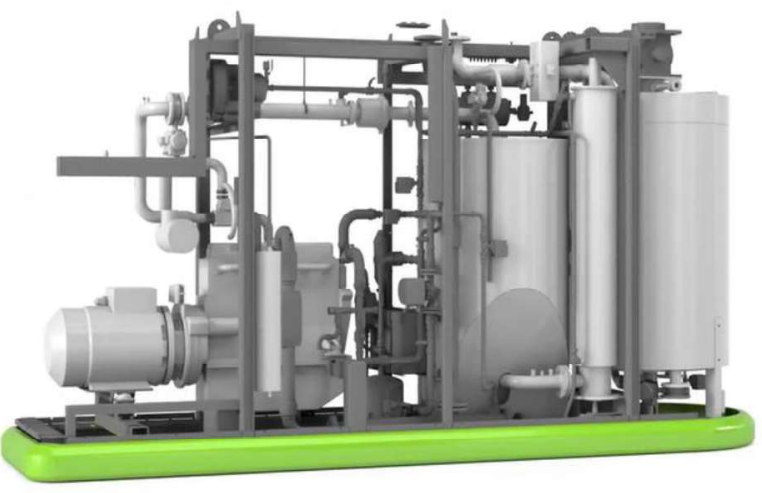

Figure 1. Biomass Combined Heat and Power Generator (Volter, 2019)

\subsubsection{Solar Photovoltaic Systems}

The solar PV arrays, shown in Figure 2, include both a CPV system and a conventional building-integrated flat panel PV system. Where conventional PV cells generate electricity from both direct and diffuse radiation, CPV systems use stationary mirrors to concentrate a large area of direct sunlight onto a small area of (typically) higher efficiency PV cells to generate electricity. The CPV controller adjusts the position of the solar cell collector to track the focal point of the mirrors across the sun's path to maximize PV energy conversion throughout the day.

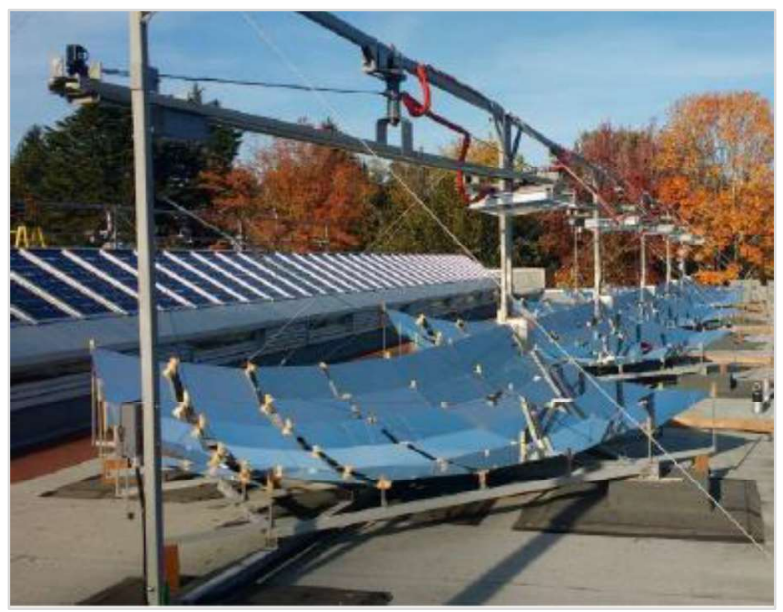

Figure 2. NRC building-integrated flat panel (background) and concentrating mirror (foreground) solar PV systems

Some advantages of CPV systems are that they require fewer expensive solar photovoltaic cells relative 
to flat panel PVs to generate the same amount of electricity. Disadvantages of CPV systems include the need for moving parts (compared with non-tracking PV systems) and large amounts of direct solar radiation. During cloud cover, CPVs will experience a significant drop in energy production, whereas a conventional PV system will still produce electricity from diffuse radiation (Kraemer, 2017). By including both types of PV systems in the facility power network, both approaches can be assessed to determine how each technology can be used to best support optimal microgrid operation.

Challenges for all PV generation systems include changes in the availability of sunlight that occur seasonally (e.g., in northern communities, there is little or no sunlight during the winter). Under more favorable conditions, energy production can still vary on the order of seconds to minutes as the result of shading caused by cloud cover, resulting in momentary energy shortfalls that need to be made up by other energy sources. For a surplus of solar energy production, if using a fixed speed diesel generator, PV output may need to be curtailed if the generator is operating at minimum loading. This is an example of where incorporating energy storage systems, such as batteries, can improve the flexibility, performance, and reliability of micro-grid operations. (NRCan 1, 2018).

\subsubsection{Diesel Generator (DG)}

The NRC micro-grid facility will include a variable speed diesel generator. Although not yet installed, a candidate $80 \mathrm{~kW}_{\mathrm{e}}$ diesel generator is shown in Figure 3.

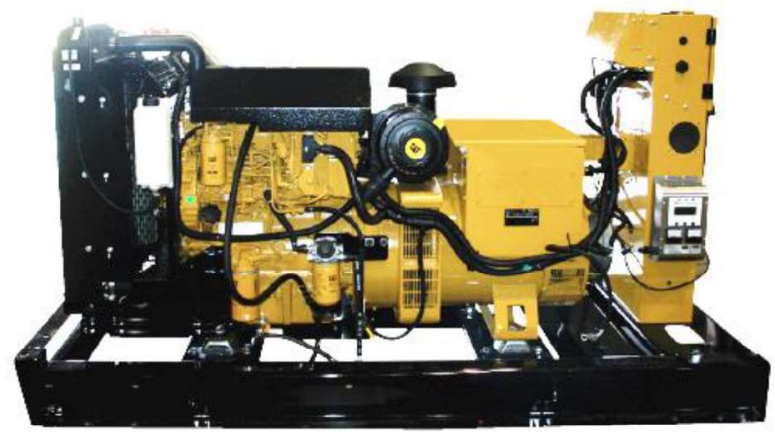

Figure 3. Variable Speed $80 \mathrm{~kW}$ Diesel Generator (Caterpillar, 2010)

Conventional fixed speed diesel generators are the most common and reliable systems for power generation; however, due to slow ramp rates, fixed speed generators can struggle to adjust their outputs in response to the variable generation from renewable sources (e.g., PV and wind). Fixed speed generators also have a minimum loading requirement (typically $30-50 \%$ of their maximum capacity) that they cannot operate below without reducing the life of the generator, preventing these systems from being significantly ramped down to reduce fuel consumption and / or accommodate an increase in renewable energy production. In addition, the fuel efficiency of a fixed speed diesel generator drops significantly when the system is operating at or near minimum loading. (NRCan 1, 2018).

Although more complex than conventional fixed speed diesel generators, variable speed generators have faster ramp rates and operate more efficiently at lower minimum loads. They also provide greater flexibility for simulating different test conditions in the context of the NRC's micro-grid facility.

\subsubsection{Energy Storage System (ESS)}

The ESS can play a key role for micro-grid systems that incorporate renewable energy sources. For example, batteries have the ability to efficiently store surplus energy from renewables or other sources and can reliably supply their stored energy at much faster ramp rates than engine-driven generators. In this way, batteries can rapidly balance power generation with demand, resulting in improved power quality, system flexibility, and stability.

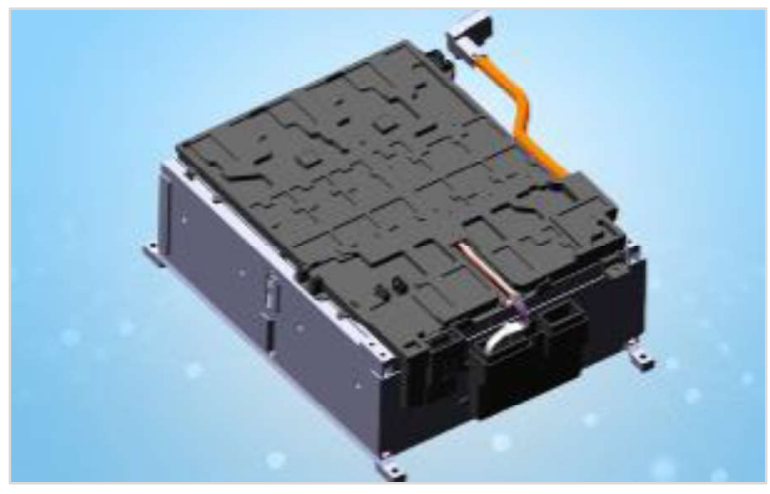

Figure 4. Single battery module from a commercial energy storage system (EV Shop, 2019)

\subsection{Micro-Grid Use Cases}

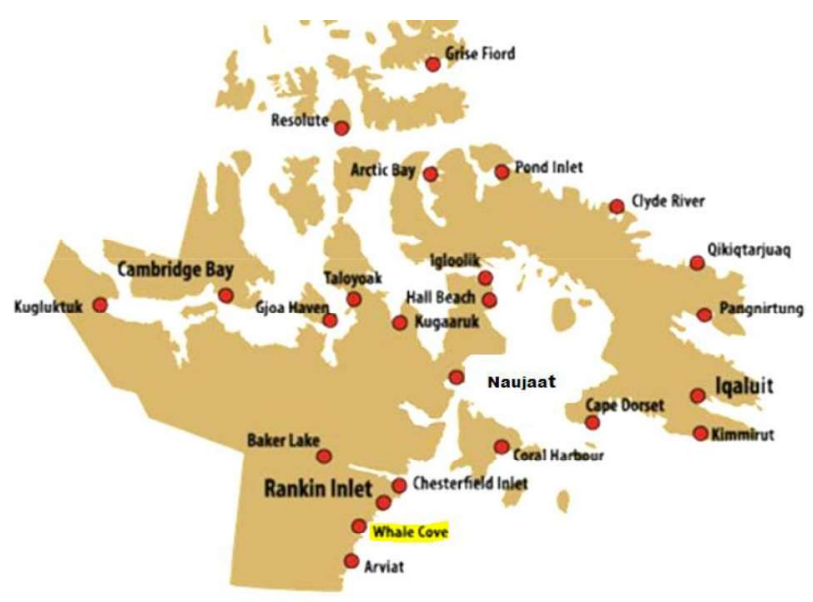

Figure 5. Qulliq Energy Corporation (QEC) partial service area map showing Whale Cove (QEC, 2018) 
For the purposes of this study, three use cases were defined and analyzed based on the remote northern community of Whale Cove, Nunavut (see Figure 5):

1. 'Island mode' operation of the Whale Cove microgrid without renewables (present state).

2. 'Island mode' operation of the Whale Cove microgrid with renewables and an energy storage system.

3. Operation of the Whale Cove micro-grid including renewables and energy storage with a grid connection to the Manitoba Electrical Grid.

For the use cases that involve renewables (Use Case 2 and 3), technologies that are currently planned / included in the NRC facility power network were explored to see how they might benefit the existing Whale Cove micro-grid. Multiple design, economic, and environmental analyses were performed.

\subsection{Micro-Grid Integrated System Model}

Although there are multiple modeling tools available for micro-grid design, simulation, and optimization, the platform selected to model the micro-grid test and training facility was the Microgrid Modelica library developed by Modelon, along with a commercial modeling and simulation platform that uses the Optimica Compiler Toolkit for model simulation and optimization (Windahl, 2019). This platform was selected based on its flexible, multi-physics, and highly customizable modeling and optimization framework using the Optimica language extension (Åkesson, 2008), its ability to accommodate models of varying levels of fidelity, its ability to provide physical (rather than only mathematical) representation of micro-grid components, and its ability to support acausal analysis. A review of this and other modeling and optimization tools has been provided by (Windahl, 2019).

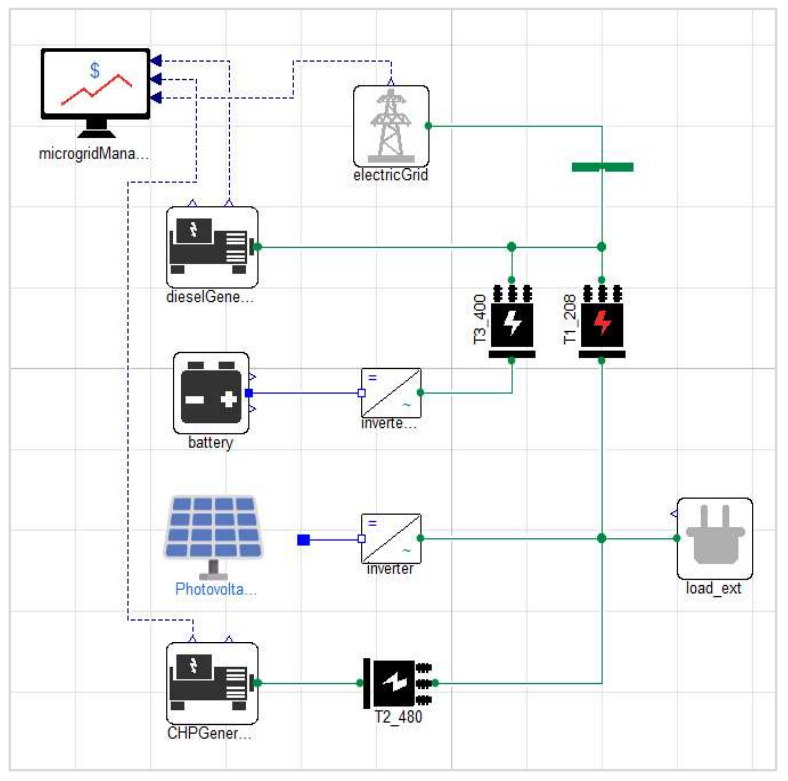

Figure 6. Micro-Grid Integrated System Model
Using the Microgrid Modelica library component models, an integrated system model (see Figure 6) was assembled, including a diesel generator, a battery-based ESS, a simple PV system, a biomass CHP generator, and a simplified representation of a grid connection, conversion components, and a configurable load.

\subsubsection{Diesel Generator Model}

The diesel generator model can be configured to represent both a fixed or variable speed diesel generator, as $\mathrm{AC}$ power is generated based on a control input signal and representative fuel consumption curve. The operational differences between the two types of generators can be defined as a function of acceptable ramp rates and load limits using a micro-grid control model (see Section 2.3.8). For the purposes of this study, however, the diesel generator was modeled as a fixed speed generator, to best represent the generators currently operating at Whale Cove.

Four generators are presently available to provide power to Whale Cove: two $300 \mathrm{~kW}$ Caterpillar D3412 units, one $150 \mathrm{~kW}$ Caterpillar D3406 unit, and one 320 kW Detroit Diesel (DD) Series 60 unit (ITP, 2019). The parameters for the diesel generator model are summarized in Table 1. Although the maximum rated capacity for Whale Cove is $1070 \mathrm{~kW}$, the max load (demand) was estimated at $402 \mathrm{~kW}$ for 2018/19 (QEC, 2017). Despite the excess capacity, it is assumed that the recent acquisition of the DD Series 60 generator signals that older generators (installed in 1991) are in need of replacement (Nunavut, 2001). It is expected that up to two of the four available generators would be operating at one time with the remaining generators operating as backups. In addition, power generation loads / losses are expected to consume $9.6 \%$ of the total energy generated in order to satisfy the power demand (QEC, 2017).

Table 1. Diesel Generator Parameters and Constraints

\begin{tabular}{|c|c|}
\hline Whale Cove & Value \\
\hline Max Electrical Load for Whale Cove ${ }^{1}$ & $402 \mathrm{~kW}$ \\
\hline Available Generator Capacity ${ }^{2}$ & $1070 \mathrm{~kW}$ \\
\hline Max Capacity (DD $60+$ D3412) ${ }^{3}$ & $620 \mathrm{~kW}$ \\
\hline Max Operating Point $(80 \% \mathrm{max})^{3}$ & $496 \mathrm{~kW}$ \\
\hline Min Loading $(30 \% \text { of DD } 60)^{4}$ & $96 \mathrm{~kW}$ \\
\hline Max Capacity for renewables 5 & $216 \mathrm{~kW}$ \\
\hline Losses / Station Loads ${ }^{1}$ & $9.6 \%$ \\
\hline Electricity Rates (averaged) ${ }^{1}$ & $\$ 1.28 / \mathrm{kWh}$ \\
\hline
\end{tabular}

${ }^{1}$ (QEC, 2017), ${ }^{2}$ (ITP, 2019), ${ }^{3}$ Based on combined capacity of DD $60+\mathrm{D} 3412=620 \mathrm{~kW}$, with a maximum operating point of up to $80 \%$ of the combined rated capacity $(620 * 80 \%=496 \mathrm{~kW})$, ${ }^{4}$ Defined for DD60 operating alone, ${ }^{5}$ Capacity for renewables defined as the max load for Whale Cove $(402 \mathrm{~kW})$ minus the combined min loading for DD 60 and D3412 $(620 * 30 \%=186$ $\mathrm{kW}): 402 \mathrm{~kW}-186 \mathrm{~kW}=216 \mathrm{~kW}$. 
Fuel consumption correlations for each generator type are listed in Table 2 (Das, 2017). Data points for each generator were plotted and used to generate a regression equation approximating the fuel consumption $(\mathrm{L} / \mathrm{h})$ as a function of power $(\mathrm{kW})$ for the four generators operating as a single unit (see Figure 7). Since it is assumed that two generators will operate together to accommodate higher loads, the regression equation does not extend beyond $\sim 80-85 \%$ of each individual generator's maximum capacity.

Table 2. Diesel Generator Parameters and Constraints

\begin{tabular}{|l|l|}
\hline \multicolumn{2}{|l|}{$\begin{array}{l}\text { Fuel Consumption Curves }(\mathrm{x}=\text { Power }[\mathrm{kW}] \\
\mathrm{y}=\text { Fuel consumption rate }[\mathrm{L} / \mathrm{h}])\end{array}$} \\
\hline${\text { Cat D } 3412^{1}}^{1}$ & $\mathrm{Y}=-0.0006 \mathrm{x}^{2}+0.5212 \mathrm{x}-15$ \\
\hline Cat D 3406 $^{l}$ & $\mathrm{Y}=-0.0004 \mathrm{x}^{2}+0.3711 \mathrm{x}-2.1447$ \\
\hline DD Series $60^{l}$ & $\mathrm{Y}=-0.0006 \mathrm{x}^{2}+0.5212 \mathrm{x}-15$ \\
\hline Lin. Approx. $^{2}$ & $\mathrm{Y}=0.3329 \mathrm{x}-2.5439$ \\
\hline
\end{tabular}

${ }^{1}$ (Das, 2017) ${ }^{2}$ Linear regression for data at $80-85 \%$ generator capacity, assuming up to two generators in operation at a time.

\section{Fuel Consumption (L/hr) vs Power (kW)}

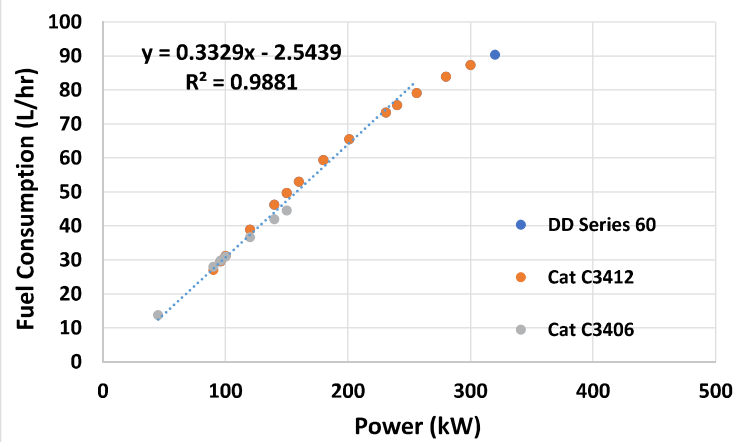

Figure 7. Diesel Consumption Correlation for Whale Cove Micro-grid Fixed Speed Generators

From (NRCan 1, 2018), the capacity to add renewables to this micro-grid was taken as the difference between the minimum loading (30\%) output of the DD 60 and D3412 diesel generators $(186 \mathrm{~kW})$ and the maximum load for Whale Cove $(402 \mathrm{~kW})$. Based on this, the resulting combined PV and CHP maximum power output was limited to $\sim 216 \mathrm{~kW}$.

For cost analyses, the total weighted average cost of diesel based electric power generation was taken as $\$ 1.28 \mathrm{CDN}$ per $\mathrm{kWh}$ based on current residential, commercial, government, and non-government consumer rates (QEC, 2017).

\subsubsection{Solar PV Model / Data}

The Microgrid library includes a PV model that can be configured to represent both flat panel PV and CPV systems, using panel surface area, solar irradiance, temperature, system capacity, and efficiency; however, for the purposes of this study, a simple PV model was used. PV DC power generation estimates were taken from the National Renewable Energy Laboratory's (NREL) PVWatts ${ }^{\circledR}$ Calculator for a flat panel solar installation, with an array tilt of $55^{\circ}$ and a system size of $176 \mathrm{~kW}$ (see Figure 8 and Figure 9). Note that PV output was limited to $176 \mathrm{~kW}$ to leave room for the $40 \mathrm{~kW}$ CHP power generator. PVWatts data is based on multi-year weather data averages for Whale Cove.

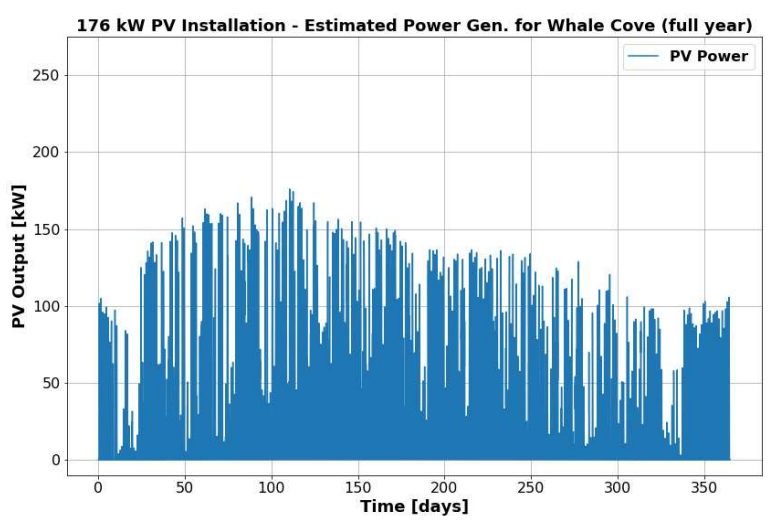

Figure 8. DC PV Power Estimates for Whale Cove (NREL, 2019)

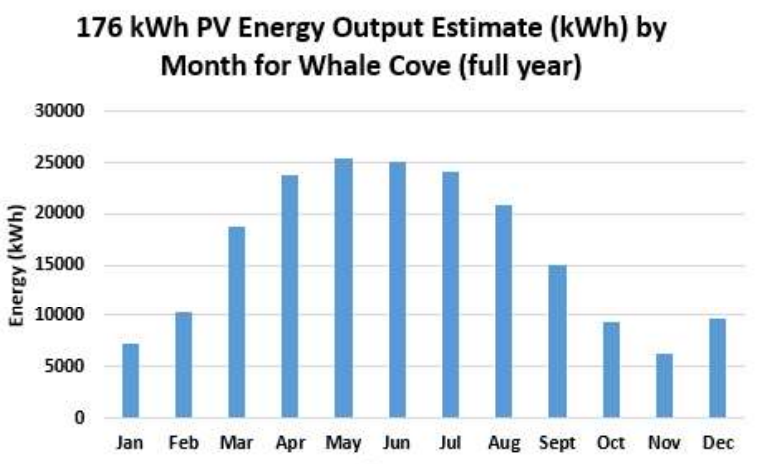

Figure 9. PV Energy Estimates for Whale Cove (NREL, 2019)

Based on the above data, the total energy produced by this installation for the full year is 195.5 MWh, equivalent to $\sim 11 \%$ of the estimated total annual energy required for Whale Cove ( 1713 MWh, see Table 6).

\subsubsection{Battery Model}

The battery system model was defined based on battery capacity, assumed minimum and maximum states of charge (SOC), and maximum charge and discharge rates. These and other relevant battery system data are listed in Table 3. Note that a detailed thermal model of the ESS was not applied for this analysis.

Table 3. Battery Model Parameters

\begin{tabular}{|l|c|}
\hline Parameter Description & Value \\
\hline Nominal Cell Capacity $^{1}$ & $120 \mathrm{Ah}$ \\
\hline Module Configuration & $12 \mathrm{~S} 1 \mathrm{P}$ \\
\hline Max SOC & $80 \%$ \\
\hline
\end{tabular}




\begin{tabular}{|l|c|}
\hline Parameter Description & Value \\
\hline Min SOC & $20 \%$ \\
\hline Discharge C-Rate $\left(20-80 \%\right.$ SOC) $^{1}$ & $2 \mathrm{C}$ \\
\hline Charge C-Rate $\left(20-80 \%\right.$ SOC) $^{1}$ & $2 \mathrm{C}$ \\
\hline Pack Configuration $^{1}$ & $98 \mathrm{~S} 1 \mathrm{P}$ \\
\hline Total Pack Energy Capacity $^{1}$ & $42.2 \mathrm{kWh}$ \\
\hline Pack Voltage $^{1}$ & $352 \mathrm{~V}$ \\
\hline
\end{tabular}

${ }^{1}$ Data based on real-world battery system characterization tests performed at NRC Vancouver battery testing labs.

\subsubsection{Transformer and Inverter Models}

Transformers and inverters were characterized using linear efficiency-based models, selectable for voltage or current type units. For this study, voltage units were used and all efficiencies were assumed to be $95 \%$ and $96 \%$ for transformers and inverters, respectively.

\subsubsection{Biomass CHP Generator Model}

Parameters for the CHP generator are shown in Table 4. For the purposes of this study, only the electric power generated by the biomass CHP system was integrated into the micro-grid model. Since the Whale Cove generating station is located on the edge of town, connecting to a heat distribution network to make use of the available thermal energy was considered to be cost prohibitive (Nunavut, 2001). Note that the CHP generator's power output was constrained to $40 \mathrm{~kW}, 3$ phase, 480 VAC. Fuel consumption was taken as 1:1 with energy output, per vendor specifications (i.e., 1 $\mathrm{kg} / \mathrm{h}$ biomass is required to generate $1 \mathrm{kWh}$ electricity) with an electrical efficiency of $20 \%$.

Table 4. CHP Model Parameters

\begin{tabular}{|l|c|}
\hline Parameters & Value \\
\hline $\begin{array}{l}\text { Rated CHP electrical / } \\
\text { thermal power capacity }^{1}\end{array}$ & $40 \mathrm{~kW}_{\mathrm{e}} / 100 \mathrm{~kW}_{\text {th }}$ \\
\hline Fuel consumption $^{1}$ & $40 \mathrm{~kg} / \mathrm{hr}$ \\
\hline Electrical efficiency $^{1}$ & $20 \%$ \\
\hline Fuel cost (see below) & $\$ 0.78 / \mathrm{kg}$ \\
\hline
\end{tabular}

${ }^{1}$ (Volter, 2019)

For cost optimizations, CHP-based electricity generation was estimated at $\$ 0.78 \mathrm{CDN}$ per $\mathrm{kWh}$ based on: a delivered cost of $\$ 300$ / ton of wood pellets (Wood, 2019), \$362 / ton shipping costs to Whale Cove from NEAS terminal in Valleyfield, QC (NEAS, 2018), \$5/ ton for storage, $5 \%$ federal goods and services tax (CRA, 2019), and a Nunavut minimum wage labor cost of $\$ 13 / \mathrm{hr}$ (GOC, 2019) with estimated $6 \mathrm{hr} /$ day operational support requirements.

\subsubsection{Ideal Grid Model}

The use case where the Whale Cove micro-grid includes a connection to the Manitoba electrical grid is based on a feasibility study performed by (Karanasios, 2016) for northern communities in Nunavut. To model this use case, an ideal grid model was used (with constant voltage and frequency). Grid power can be purchased at a cost of $\$ 0.13 / \mathrm{kWh}$ and sold back to the grid for $\$ 0.02949$ / kWh (see Table 5). To connect 1,000 km of transmission lines to multiple Nunavut communities in the area, the estimated cost (in 2015) was $\sim \$ 900$ million, with $\$ 40$ million in diesel savings estimated per year. This cost was assumed to have been reflected in the $\$ 0.13$ / $\mathrm{kWh}$ rate, since Manitoba commercial large service rates are $\$ 0.075 / \mathrm{kWh}$ (Hydro Manitoba, 2021) and the project's estimated 40-year lifetime to achieve a return on investment. (Karanasios, 2016).

Table 5. Grid Parameters

\begin{tabular}{|l|c|}
\hline Manitoba Grid Connection & Value \\
\hline Grid Purchase Rate for QEC & $\$ 0.13 / \mathrm{kWh}$ \\
\hline Grid Selling Rate $^{2}$ & $\$ 0.02949 / \mathrm{kWh}$ \\
\hline
\end{tabular}

${ }^{1}$ (Karanasios, 2016), ${ }^{2}$ (Hydro Manitoba, 2021) - May vary slightly, as this rate applies for $\leq 100 \mathrm{~kW}$ systems.

\subsubsection{Load Data}

The load for each simulation was supplied as a variable input from a real-world load profile sampled at 15 minute intervals (see Figure 10). In the absence of measured data from Whale Cove, load data derived from Old Crow (a northern community in the Yukon) was used. The load data was scaled by a factor of 0.74 to maintain the max load constraint of $\sim 402 \mathrm{~kW}$ for Whale Cove. In addition, all zero load values were updated to their last non-zero value to avoid a no-load condition during simulation.

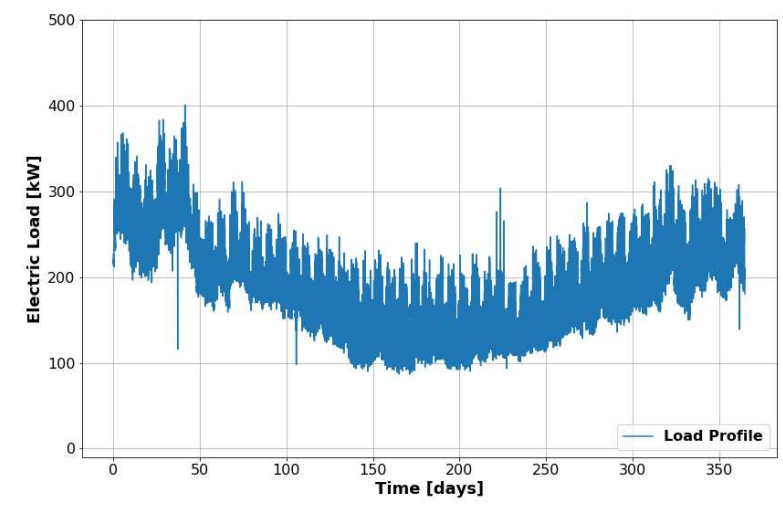

Figure 10. Scaled Jan-Dec 2015 load profile from Old Crow, Yukon (ATCO Electric Yukon, 2015)

Although Old Crow is situated further north, review of the scaled dataset shows that the annual energy consumed (MWh) is a close match to QEC's published values for annual energy consumption in 2015 for Whale Cove (see Table 6). Based on this, the data set was assumed to be a sufficiently reasonable representation of both daily use and seasonal load variations for Whale Cove. 
Table 6. Load Data Validation

\begin{tabular}{|l|c|}
\hline Community & $M W h$ \\
\hline Scaled Old Crow, Yukon $^{1}$ & 1713 \\
\hline Whale Cove, Nunavut $^{2}$ & 1732 \\
\hline
\end{tabular}

${ }^{1}$ Calculated from load data file (ATCO Electric Yukon, 2015),

${ }^{2} 2015$ MWh, avg. MWh for 2014/15 and 2015/16 (QEC, 2017)

\subsubsection{Microgrid Control and Economy Models}

The Microgrid Modelica library includes a micro-grid controller 'MicroGridControl', which contains the control rules for each controllable micro-grid component that is applicable to each use case (additional details provided below). In addition, the library includes an 'Economy' model that computes the cost for each power source.

\section{Micro-Grid Analysis}

\subsection{Use Case 1 Simulation}

The first use case analyzed the present diesel generator's ability to meet the power demand at Whale Cove. This simulation was performed as an initial validation of the integrated system model with respect to calculated power / energy generation, fuel consumption, cost, and GHG emissions (typically quantified as $\mathrm{kg} \mathrm{CO}_{2 \mathrm{e}}$ ), as well as for comparison with subsequent use cases. $\mathrm{CO}_{2 \mathrm{e}}$ emissions are defined as the $\mathrm{CO}_{2}$ equivalent emissions for all combustion products $\left(\mathrm{CO}_{2}, \mathrm{NOx}, \mathrm{HC}\right.$, or other GHGs). An electricity generation rate of $\$ 1.28 / \mathrm{kWh}$ was used for diesel-only power generation (see Table 1). $\mathrm{CO}_{2 \mathrm{e}}$ emissions were taken as $2.679 \mathrm{~kg} \mathrm{CO}_{2 \mathrm{e}}$ per liter of diesel fuel (BCME, 2014).

\subsection{Use Case 2 Simulation}

The second use case evaluated the present micro-grid operating configuration at Whale Cove with renewables and energy storage added. This included the biomass CHP system, PVs, and a battery ESS.

The first analysis looked at the system's ability to match power / energy generation with demand curves using a rule-based simulation. For micro-grid reliability, the diesel generator was not permitted to operate below $30 \%$ or above a maximum of $80 \%$ of its rated capacity, with the CHP system and PVs meeting the remaining demand. Batteries were directed to discharge (supply) power when a shortfall was detected, and to charge power when there was a surplus (up to a maximum $2 \mathrm{C}$ charge / discharge rate). If power generated was in excess of the demand and available battery capacity, the CHP and PV outputs were curtailed.

Initial simulations were run on Day 0 (winter) and Day 220 (summer) to validate the rule-based simulations response with surplus power (Day 220) and without surplus power (Day 0). Once verified, a simulation was performed for the full year to identify seasonal variations with respect to renewable power generation and consumer demand, and for comparison with diesel-only operation (Use Case 1).

Subsequent analyses assess the impact of various parameters or operating strategies on cost, fuel consumption, and $\mathrm{CO}_{2 \mathrm{e}}$ emissions, including:

- PV installation size

- Selective use of renewables (i.e. PV only, or CHP only)

- Operating strategies based on seasonal variations

- Battery size under the various operating scenarios considered above (with the goal of eliminating the need for curtailment).

\subsection{Use Case 3 Simulation and Optimization}

The third use case adds a bi-directional grid connection to the Manitoba electric system. A $\$ 0.13 / \mathrm{kWh}$ purchase rate and $\$ 0.02949 / \mathrm{kWh}$ selling rate were used (see Table 5). Power was purchased from the grid when a shortfall was detected and sold back to the grid when there was a surplus. For reliability, the diesel generator was not permitted to operate below $30 \%$ of its rated capacity

\section{Results \& Discussion}

\subsection{Use Case 1 Simulation}

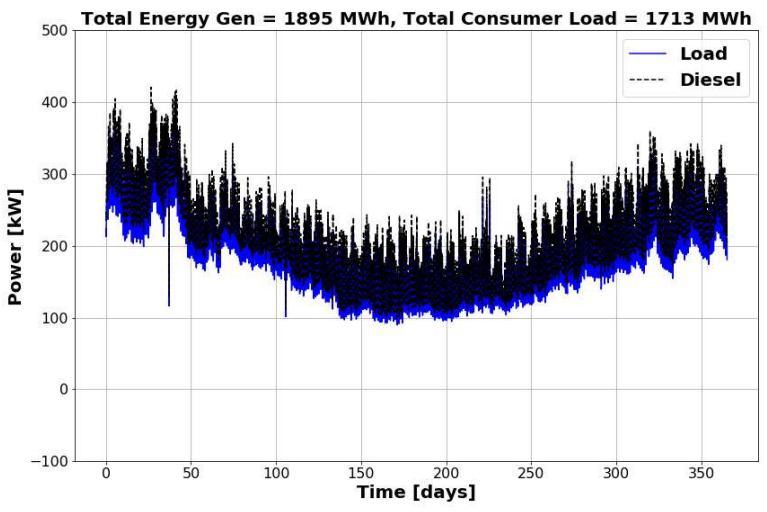

Figure 11. Use Case 1 - Whale Cove power generation using diesel generators only (full year)

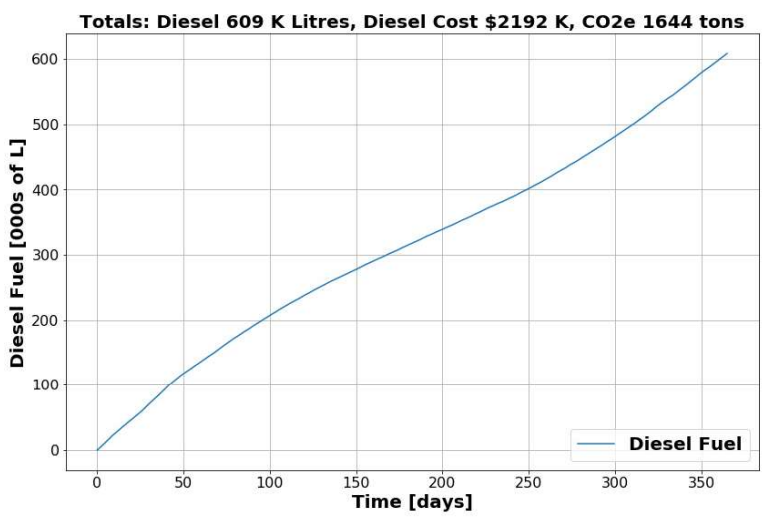

Figure 12. Use Case 1 Simulation - Baseline cost for diesel-only power generation (full year) 
The results for Use Case 1, micro-grid operation with the diesel generator only, are shown in Figure 11 and Figure 12. Diesel power is shown to correctly track load over the course of the simulation, with a slightly higher power output level than consumer loads to cover upstream losses and station loads (see also, Table 1). A comparison of literature values ('Ref. Data'), independently calculated values using load data in Excel ('Calc. Data'), and simulation results ('Sim. Data') are provided in Table 7.

Table 7. Baseline Simulation Validation

\begin{tabular}{|c|c|c|c|}
\hline Descript. & Ref. Data $^{l}$ & Calc. Data $^{2}$ & Sim. Data $^{3}$ \\
\hline Load (kWh) & $1732 \mathrm{~K}$ & $1713 \mathrm{~K}$ & $1713 \mathrm{~K}$ \\
\hline Gen (kWh) & $1910 \mathrm{~K}$ & $1895 \mathrm{~K}$ & $1895 \mathrm{~K}$ \\
\hline Fuel (L) & $532 \mathrm{~K}$ & $609 \mathrm{~K}$ & $609 \mathrm{~K}$ \\
\hline $\mathrm{CO}_{2 \mathrm{e}}$ (tons) & 1479 & 1644 & 1644 \\
\hline $\begin{array}{c}\text { Cost } \\
(\mathrm{CDN} \$)^{4}\end{array}$ & $2216 \mathrm{~K}$ & $2192 \mathrm{~K}$ & $2192 \mathrm{~K}$ \\
\hline
\end{tabular}

${ }^{1}$ (QEC, 2017) and (ITP, 2019), ${ }^{2}$ Calculated independently in Excel using scaled load data file (ATCO Electric Yukon, 2015), ${ }^{3}$ Results calculated from model / simulation, ${ }^{4}$ Based on load $(\mathrm{kWh})$ at $\$ 1.28 / \mathrm{kWh}$ (present day averaged cost).

Calc. Data and Sim. Data are equivalent, as required. All corresponding values in Table 7 compare closely with published data for Whale Cove, with the most notable discrepancy being fuel consumption and $\mathrm{CO} 2$ emissions. A closer evaluation reveals that QEC uses a fuel efficiency value of $3.6 \mathrm{kWh} / \mathrm{L}$ as a compared to a $3.1 \mathrm{kWh} / \mathrm{L}$ average fuel efficiency value derived here from the diesel consumption curves shown Figure 7. Using QEC's efficiency value, both the Excel and simulation calculations for annual fuel consumption are $512 \mathrm{~K}$ liters (vs. $532 \mathrm{~K}$ liters from QEC). Since $\mathrm{CO}_{2 \mathrm{e}}$ is directly proportional to fuel consumption, these values follow. However, it is noted that values used by (ITR, 2019) are based on more recent actual data with slightly higher load values (1755 K kWh) and an average fuel efficiency of $3.2 \mathrm{kWh} / \mathrm{L}$. Since load discrepancies are expected, based on using the scaled load profile from Old Crow rather than Whale Cove, and since fuel efficiency values from (ITR, 2019) are much closer to the average efficiency values derived from the fuel consumption curves, the diesel consumption rates and $\mathrm{CO}_{2 \mathrm{e}}$ emissions rates used by this study were deemed acceptable and retained for the remainder of the analysis.

In addition to the results shown above, the 'net power' was plotted versus time (see Figure 13). For this use case, the net power represents the total minimum diesel electric power generated (at minimum loading, or $30 \%$ of the generator's rated capacity: $96 \mathrm{~kW}$ ) minus the demand (load):

$$
P_{\text {net }}=\text { Min Diesel }(96 \mathrm{~kW})-\text { Load }
$$

This chart shows that the diesel generator will always need to operate above minimum loading of $96 \mathrm{kWh}$ (see Table 1) to generate enough power to meet the demand. Alternately, it indicates that there is an opportunity for renewables to displace diesel on a continuous basis.

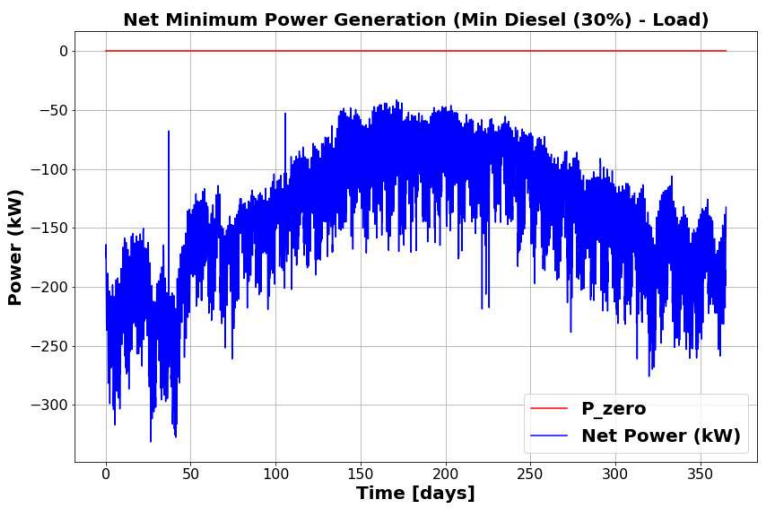

Figure 13. Use Case 1 Simulation - Net Power (full year)

\subsection{Use Case 2 Simulation and Optimization}

Initial results for Use Case 2 (micro-grid operation with a diesel generator, CHP generator, PVs, and a battery ESS) are shown in Figure 14. For both Day 0 (winter) and Day 220 (summer), the total power generated from all sources directly matches the load (with line losses accounted for), providing some initial validation of the rule-based simulation.
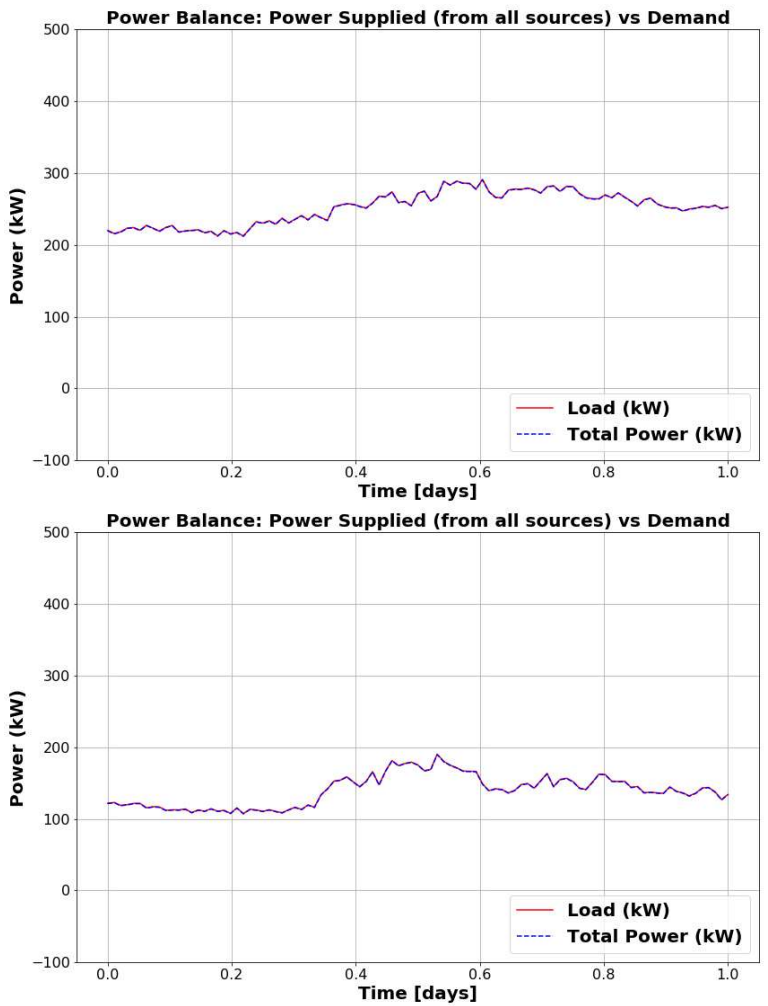

Figure 14. Use Case 2 Power Balance - Top: Day 0 (winter) and Bottom: Day 220 (summer) 
These results also show that:

- The demand in winter is almost $100 \mathrm{~kW}$ higher than the demand in summer.

- The total demand in summer is very close to the minimum loading level $(96 \mathrm{~kW})$ for the diesel generator (showing that there is more room to accommodate power from renewables in the winter than in the summer).

The simulation results in Figure 15 show the power generation from each source with respect to load for Day 0 . These results show the system behaving in accordance with the rules defined in the micro-grid controller (see Section 3.2). The diesel MG ('microgrid') power is tracking below the load level, as the CHP generator is now providing a continuous $40 \mathrm{~kW}$ power output to the micro-grid. Since the initial SOC is set at $50 \%$, at the beginning of the simulation, the battery is supplying power (discharging), until it reaches its minimum state of charge $(20 \%)$. Midday, when PV power is available, the diesel power output is reduced accordingly (but still remains above the $96 \mathrm{~kW}$ minimum loading level). Because there is no case where there is surplus of power, the battery does not have the opportunity to recharge.

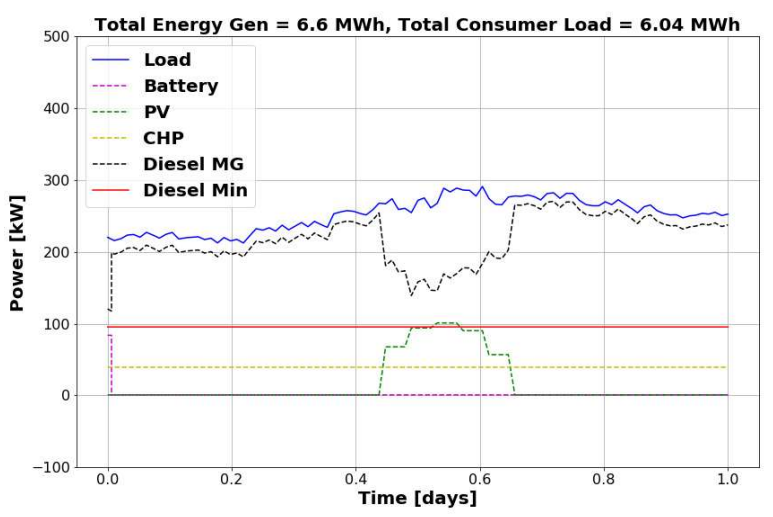

Figure 15. Use Case 2 - Day 0 - Power Generation

In Figure 16 and Figure 17, the operating costs, fuel consumption, and $\mathrm{CO}_{2 \mathrm{e}}$ emissions are shown for Day 0 .

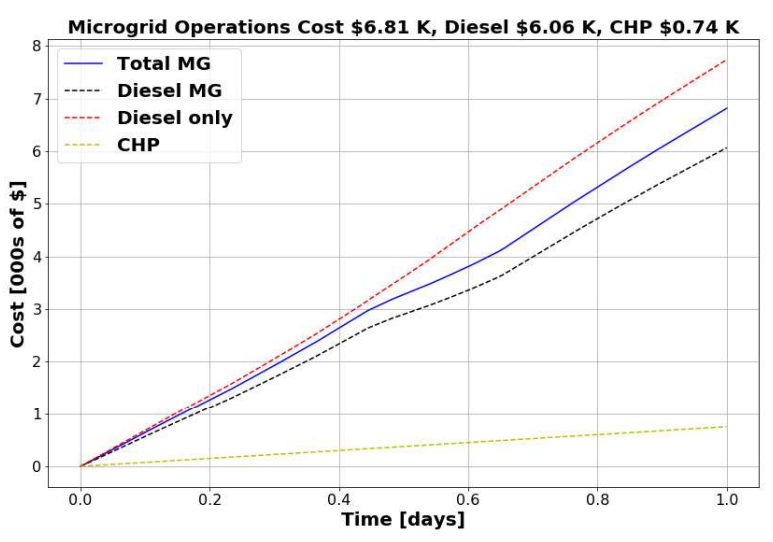

Figure 16. Use Case 2 - Day 0 - Operating Costs

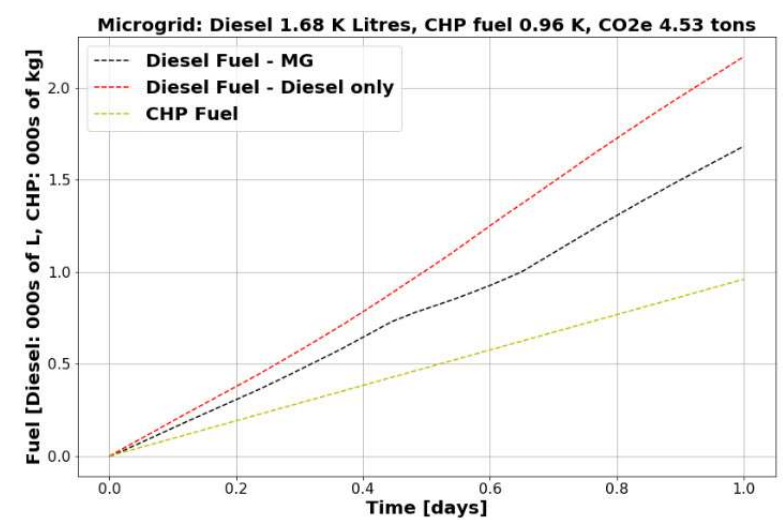

Figure 17. Use Case 2 - Day 0 - Fuel and $\mathrm{CO}_{2 \mathrm{e}}$

In each chart, the Use Case 1 results (diesel-only) are compared with Use Case 2 results (diesel plus renewables and energy storage). Table 8 provides a detailed comparison between these two use cases.

Table 8. Simulation Use Case $1 \& 2$ Comparison - Day 0

\begin{tabular}{|l|c|c|}
\hline Description & Use Case 1 & Use Case 2 \\
\hline $\begin{array}{l}\text { Total Energy } \\
\text { Generated (MWh) }\end{array}$ & 6.8 & 6.6 \\
\hline Diesel Fuel (L) & $2.16 \mathrm{~K}$ & $1.68 \mathrm{~K}$ \\
\hline CHP Fuel (kg) & -- & $0.96 \mathrm{~K}$ \\
\hline $\mathrm{CO}_{2 \mathrm{e}}($ tons) & 5.85 & 4.53 \\
\hline Cost (CDN\$) & $7.74 \mathrm{~K}$ & $6.8 \mathrm{~K}$ \\
\hline Load $(\mathrm{MWh})$ & 6.04 & 6.04 \\
\hline
\end{tabular}

For Day 0 (winter), after only 1 day of operation, the results show a reduction in diesel consumption, $\mathrm{CO}_{2 \mathrm{e}}$ emissions, and micro-grid operating costs. In addition, the total energy that must be generated by the system is lower than in the diesel-only case. This is the result of having a higher PV load line efficiency $(0.96)$ compared to the diesel load line efficiency (0.903).

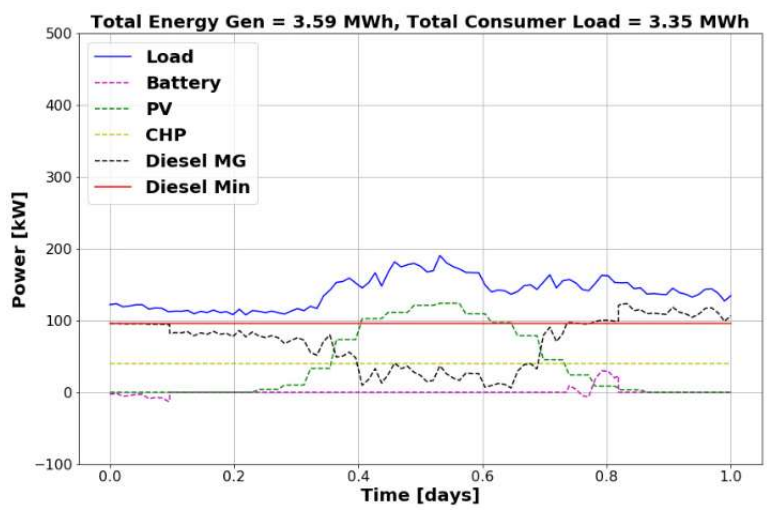

Figure 18. Use Case 2 - Day 220 - Power Generation

On Day 220 (summer), with lower overall demand and higher PV power generation relative to Day 0 (winter), a power surplus exists for a large part of the day. In order to define 'surplus' power for Use Case 2, net power needs to be defined. 
For Use Case 2, net power is defined as:

$$
\begin{gathered}
P_{\text {net }}=\text { Min Diesel }(96 \mathrm{~kW})+\text { CHP }(40 \mathrm{~kW}) \\
+ \text { PV power }- \text { Load }
\end{gathered}
$$

Surplus power will exist when the net power exceeds both the load and the available capacity of the battery to store the excess energy. At the beginning of the simulation, the battery can be seen to initially charge due to the availability of surplus power. Once the battery is fully charged, however, the diesel generator power setpoint dropped below the acceptable minimum loading level (red line), risking possible damage to the generator. Midday, as PV power became available, the diesel generator power continued to be driven down well below acceptable operating levels. To resolve this, the simulation was re-run with CHP and excess PV power curtailed (see Figure 19).

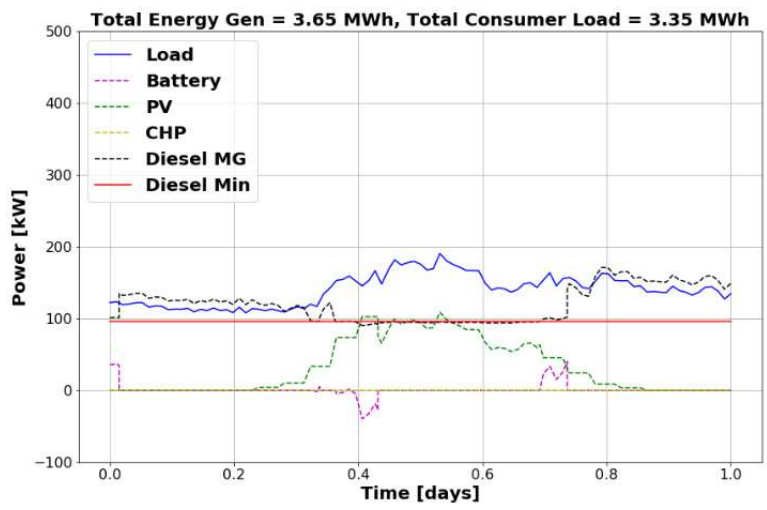

Figure 19. Use Case 2 - Day 220 - Power Generation with curtailment

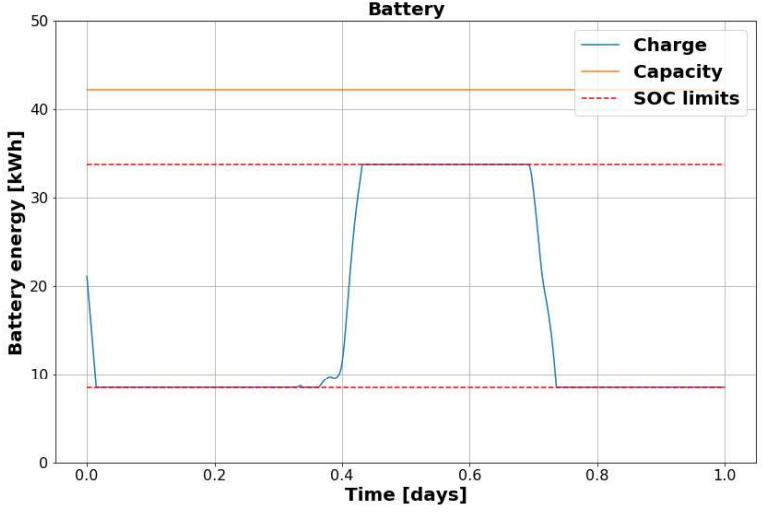

Figure 20. Use Case 2 - Day 220 - Battery Response with CHP and PV curtailment

Figure 19 shows Day 220 with the CHP system offline and excess PV output curtailed. With the reduction in power from renewables, the diesel generator is able to track near or above its minimum loading level. The battery can also be seen to charge when there is a surplus, and discharge when PV output starts to drop, while respecting SOC limits (see Figure 20). Table 9 shows the detailed comparison between the diesel-only and curtailed Day 220 simulation results.
Despite taking the CHP system offline and curtailing PV power, improvements can still be observed. Note again that the total energy generation required is lower for the micro-grid with renewables and storage, as it is more efficient than the diesel-only use case.

Table 9. Simulation Use Case $1 \& 2$ Comparison - Day 220 - Curtailed

\begin{tabular}{|c|c|c|}
\hline Description & Use Case 1 & Use Case 2 \\
\hline $\begin{array}{c}\text { Total Energy Generated } \\
(\mathrm{MWh})\end{array}$ & 3.71 & 3.65 \\
\hline Diesel Fuel (L) & $1.17 \mathrm{~K}$ & $0.89 \mathrm{~K}$ \\
\hline CHP Fuel (kg) & -- & -- \\
\hline $\mathrm{CO}_{2 \mathrm{e}}($ tons) & 3.17 & 2.41 \\
\hline Cost $(\mathrm{CDN} \$)$ & $4.29 \mathrm{~K}$ & $3.32 \mathrm{~K}$ \\
\hline Load $(\mathrm{MWh})$ & 3.35 & 3.35 \\
\hline
\end{tabular}

With the Day 0 and Day 220 results verified, the next step was to run the simulation for the full year with CHP and PV at full power to determine seasonally when a 'Day 0' approach (without curtailment) or a 'Day 220' approach (with curtailment) could be beneficial. From the plot of net power $\left(P_{n e t}\right)$ versus time, surplus power could be expected between $\sim$ Day 50 and 300, when $P_{\text {net }}$ $\geq 0$ (see Figure 21). By operating the micro-grid without CHP during these periods of surplus, the net power can be reduced to minimize PV curtailment.

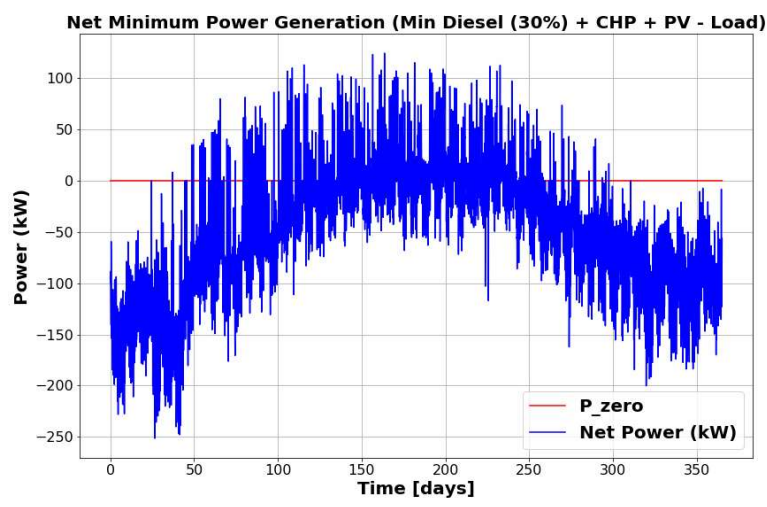

Figure 21. Use Case 2 - $P_{\text {net }}$ without curtailment (full yr)

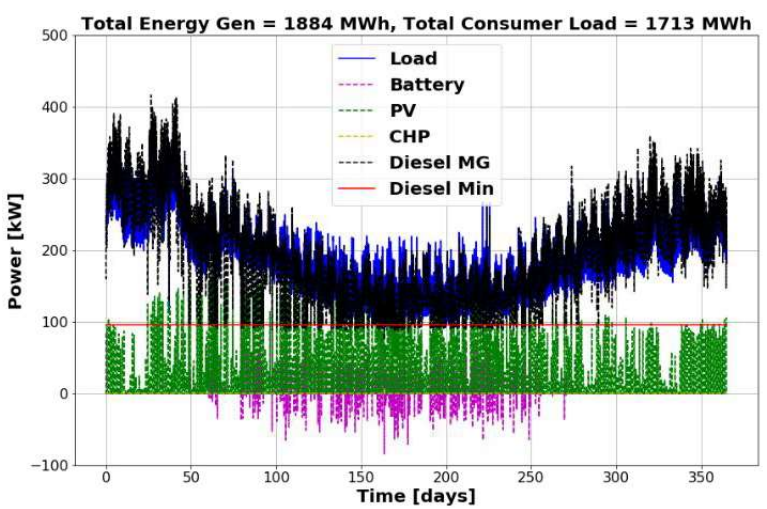

Figure 22. Use Case 2 - Power Generation with curtailment (full year). 
For the purposes of this analysis, 'seasonal' operations have been defined as running the micro-grid without curtailment of renewables in the winter, when there is higher consumer demand and lower PV production, and with curtailment (shutting the CHP generator down and curtailing excess PV power) in the summer, when demands are lower and PV production is higher. As a basis for comparison, the simulation for Use Case 2 was re-run with curtailment for the full year (see Figure 22). The simulations were then re-run without curtailment for Days 0-50 and Days 300-365, and with curtailment for Days 50 to 300 . The total energy generated, fuel consumption, $\mathrm{CO}_{2 \mathrm{e}}$, and cost (in Canadian dollars) were then added together to compare the benefits of taking a seasonal operating approach. The results of this comparison are provided in Table 10.

Table 10. Simulation Comparison - Seasonal Operation

\begin{tabular}{|c|c|c|c|}
\hline Description & $\begin{array}{c}\text { Curtailed } \\
\text { (full year) }\end{array}$ & $\begin{array}{c}\text { Seasonally } \\
\text { Curtailed }\end{array}$ & $\begin{array}{c}\text { Diesel- } \\
\text { Only Use } \\
\text { Case 1 }\end{array}$ \\
\hline $\begin{array}{c}\text { Total Energy } \\
\text { Generated } \\
\text { (MWh) }\end{array}$ & 1884 & 1890 & 1895 \\
\hline $\begin{array}{c}\text { Diesel Fuel } \\
\text { (L) }\end{array}$ & $544 \mathrm{~K}$ & $506 \mathrm{~K}$ & $609 \mathrm{~K}$ \\
\hline $\begin{array}{c}\text { CHP Fuel } \\
\text { (kg) }\end{array}$ & -- & $110 \mathrm{~K}$ & -- \\
\hline $\mathrm{CO}_{2 \mathrm{e}}$ (tons) & 1470 & 1365 & 1644 \\
\hline Cost (CDN\$) & $1969 \mathrm{~K}$ & $1920 \mathrm{~K}$ & $2192 \mathrm{~K}$ \\
\hline
\end{tabular}

Although the energy efficiency of full curtailment is slightly higher, taking a seasonal approach results in the lowest operating cost, diesel consumption, and $\mathrm{CO}_{2 \mathrm{e}}$ emissions.

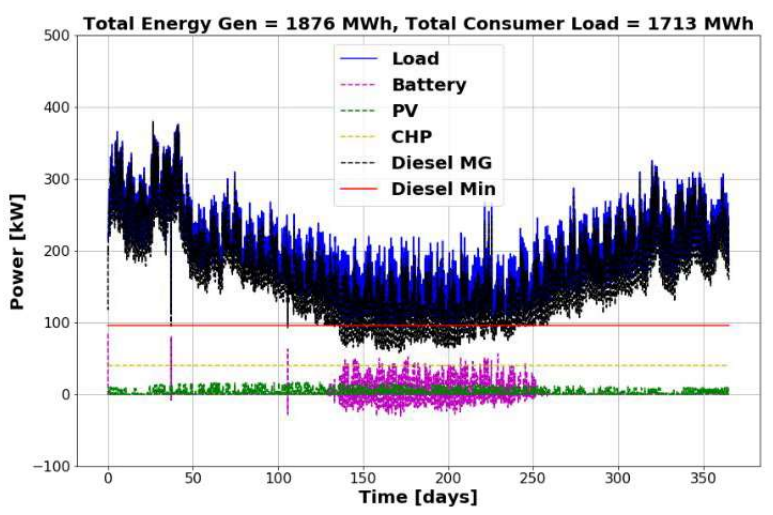

Figure 23. Use Case 2 - Power Generation without curtailment - PV installation re-scaled to $10 \%$

The next analyses look at the impact of various parameters or operating strategies on cost, fuel consumption, and $\mathrm{CO}_{2 \mathrm{e}}$ emissions. First, simulations were run to see how a change in size of the PV installation would impact the overall cost, fuel consumption and $\mathrm{CO}_{2 \mathrm{e}}$ emissions. Multiple simulations were run with the PV installation re-scaled from 0.1 to 1.0 of its current size $(176 \mathrm{~kW})$ initially without curtailment; however, even at the lowest PV installation size $(10 \%$ of $176 \mathrm{~kW})$, the diesel generator was forced to drop below its minimum loading level in the summer to accommodate surplus power (see Figure 23), getting progressively worse as the installation size increased. Simulations were next re-run with curtailment. The results are included in Figure 24.
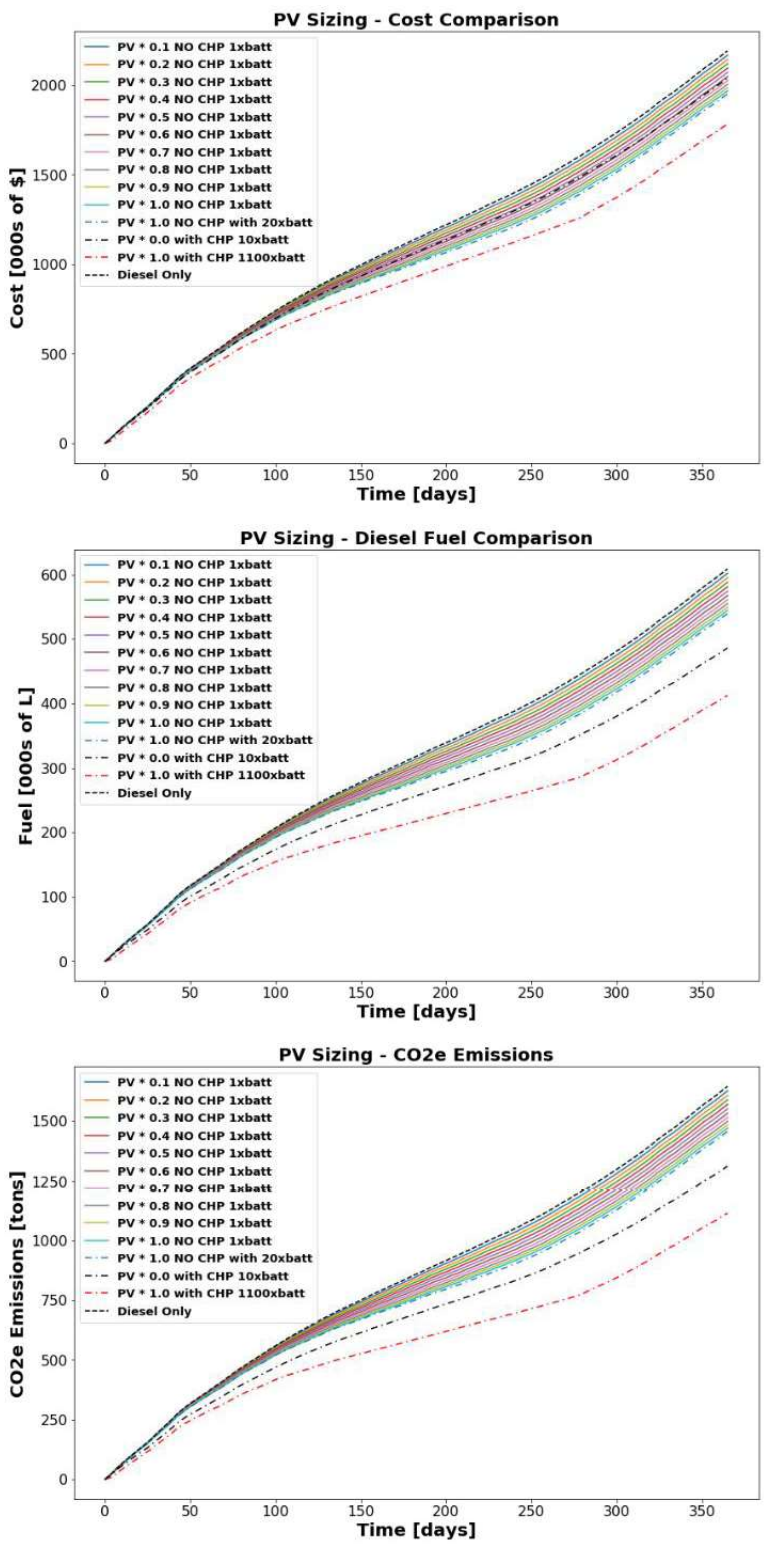

Figure 24. Use Case 2 - Impact on Cost, Fuel, and $\mathrm{CO}_{2 \mathrm{e}}$ for changes in PV size, battery size, and ops. (full year)

The black dashed line at the top of each plot in Figure 24 shows the diesel-only (Use Case 1) results for cost, fuel, and emissions for comparison. The next ten lines in the plot show how these same parameters vary with $\mathrm{PV}$ installation size, ranging from $17.6 \mathrm{~kW}(0.1 \mathrm{x}$ original PV installation size $)$ to $176 \mathrm{~kW}(1.0 \mathrm{x}$ original 
PV installation size). CHP was offline for each of these simulations, and excess PV power was curtailed, as required. Initial review of this data showed that during the winter season ( $\sim$ Day 0-50 and 300-365), the cost, fuel consumption, and emissions were largely unaffected by the PV size, as the PV energy generation was low (relative to other sources) due to the limited availability of winter sunlight. During the rest of the year, the differences with respect to installation size became more apparent, with all parameters decreasing with respect to PV size. Note that in all cases, PV curtailment was required. Because the amount of surplus power that needed to be curtailed increased with increasing PV size, eventually the benefit of increasing PV size diminishes. Although this was not easy to see in the initial $0.1-1.0$ test range, the range was expanded incrementally up to $2.0 \mathrm{x}$ original PV installation size. The results are shown in Figure 25. Note that only operating cost was shown, as $\mathrm{CO}_{2 \mathrm{e}}$ emissions are directly proportional to the fuel used, which is directly proportional to cost.

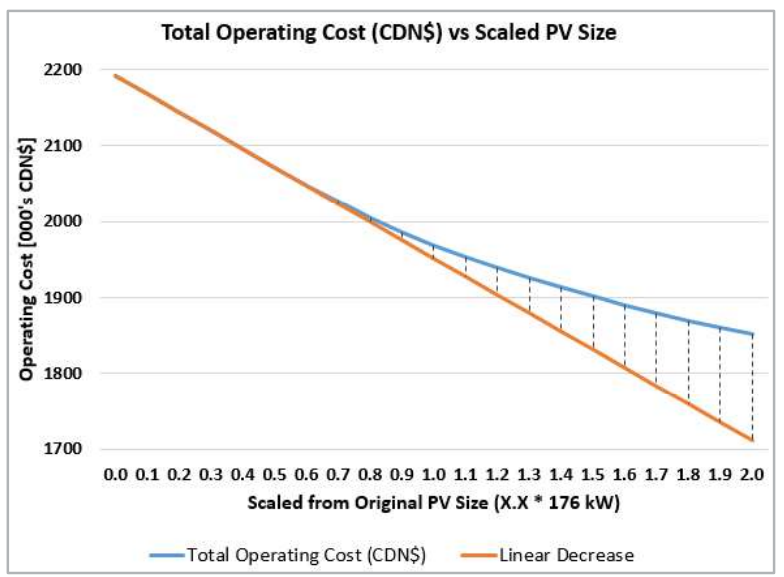

Figure 25. Use Case 2 - Total Operating Cost $(\$ C D N)$ vs Scaled PV Size (full year)

In addition to varying $\mathrm{PV}$ installation size, micro-grid operation was also simulated with CHP and energy storage only (i.e., PV output $=0 \mathrm{~kW}$ ). As with the PV simulations, there was substantial surplus power that needed to be curtailed to maintain balance, implying that the battery was largely undersized for this installation. To address this, multiple simulations were run for PV only, CHP only, and PV / CHP combined operation to find the battery size that eliminated the need for curtailment. The results are shown in Figure 26, and were included in Figure 24 for comparison with previous simulations. In each chart, the greatest reduction possible is when both CHP and full PV power are available with no surplus power (i.e., when the battery is large enough that no curtailment is needed). For the case where CHP and PV are available continuously throughout the year, a battery size of 1100 * $42.2 \mathrm{kWh}$ was required to eliminate the need for curtailment; when operated seasonally, however (with
CHP offline from Days 50-300), the battery size could be substantially reduced down to $20 * 42.2 \mathrm{kWh}$ while still achieving the same reduction in cost, diesel fuel consumption, and $\mathrm{CO}_{2 \mathrm{e}}$ emissions. This demonstrates the importance of accounting for seasonal differences when developing operating strategies for these communities.
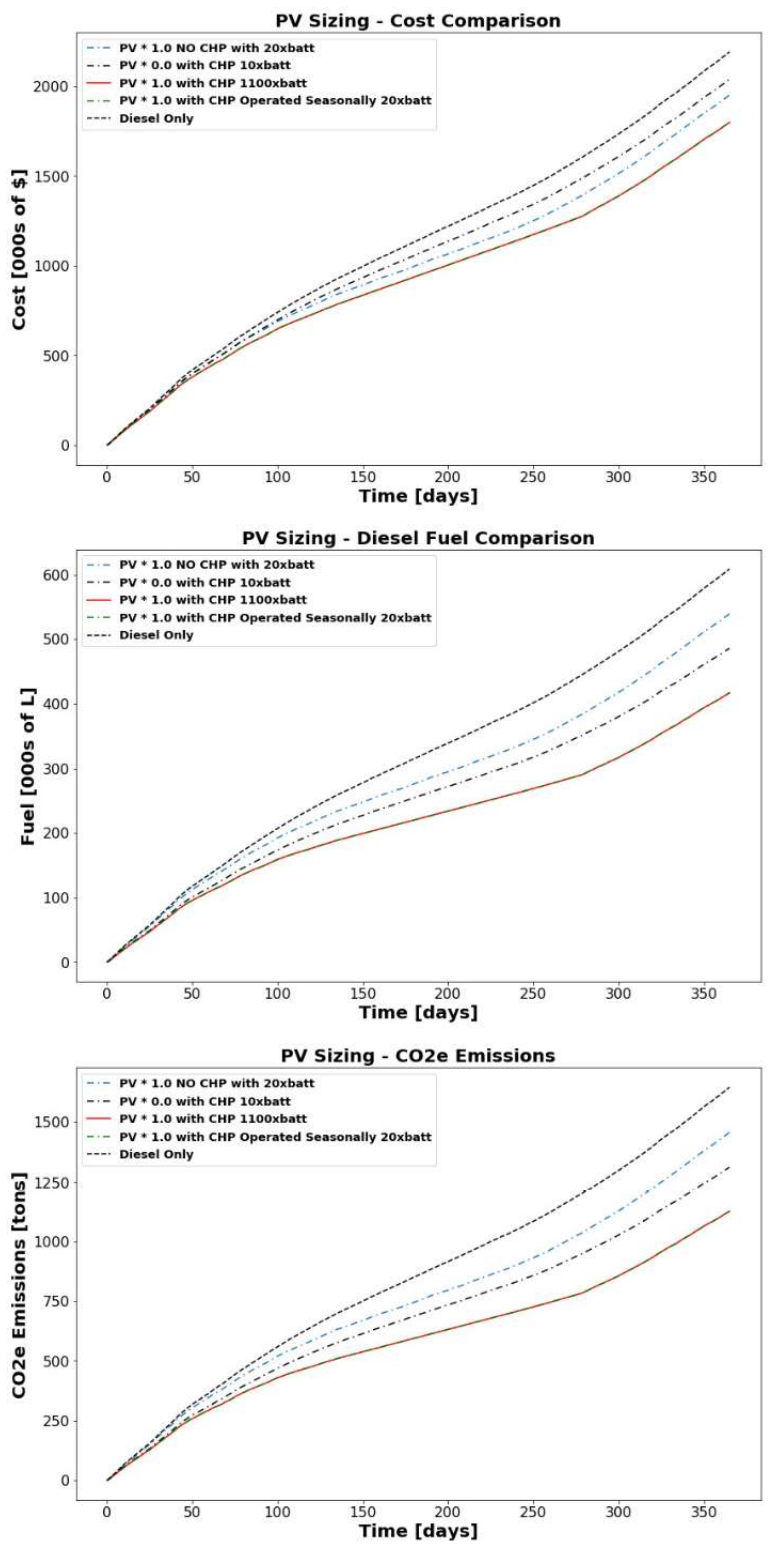

Figure 26. Use Case 2 - Impact on Cost, Fuel, and $\mathrm{CO}_{2 \mathrm{e}}$ for changes in PV size, battery size, and ops. (full year)

Having looked at optimal micro-grid component sizing and operating strategies, the next step is to look at the investment cost of each micro-grid component. For each case study shown in Figure 26, the cost of the installation and return on investment was computed. For PV system costs, the cost of $\$ 2.85$ (CDN\$) / Wac was used to include inverter costs (NREL, 2017). For the battery system, \$509 (CDN\$) / $\mathrm{kWh}$ was used, which 
includes battery management and inverter costs (NREL, 2019a). The total cost for the $40 \mathrm{~kW}$ CHP generator unit was $\sim$ \$290K (or, \$7.25 (CDN\$) / Wac) (Volter, 2016).

\begin{tabular}{|c|c|c|c|c|c|}
\cline { 2 - 6 } \multicolumn{1}{c|}{} & $\begin{array}{c}\text { Operating Cost } \\
\text { (000's SCDN) }\end{array}$ & $\begin{array}{c}\text { CO2e } \\
\text { Emissions } \\
\text { (tons) }\end{array}$ & $\begin{array}{c}\text { Annual Sarings } \\
\text { (000's SCDN) }\end{array}$ & $\begin{array}{c}\text { Installation } \\
\text { (000's SCDN) }\end{array}$ & $\begin{array}{c}\text { Break } \\
\text { Eren (yrs) }\end{array}$ \\
\hline Diesel Only & $2192 \mathrm{~K}$ & 1644 & 0 & 0 & 0.00 \\
\hline PV Only (17.6 kW) & $2168 \mathrm{~K}$ & 1625 & $24 \mathrm{~K}$ & 71.6 & 2.98 \\
\hline PV Only (176 kW) & $1969 \mathrm{~K}$ & 1470 & $223 \mathrm{~K}$ & 523.1 & 2.35 \\
\hline $\begin{array}{c}\text { PV Only (176 kW) } \\
\text { +20xBatt }\end{array}$ & $1951 \mathrm{~K}$ & 1456 & $241 \mathrm{~K}$ & 931.2 & 3.86 \\
\hline $\begin{array}{c}\text { Seasonal Ops } \\
\text { (see Table 10) }\end{array}$ & $1920 \mathrm{~K}$ & 1365 & $272 \mathrm{~K}$ & 813.1 & 2.99 \\
\hline $\begin{array}{c}\text { CHP Only + } \\
\text { 10xBatt }\end{array}$ & $2039 \mathrm{~K}$ & 1312 & $153 \mathrm{~K}$ & 504.8 & 3.30 \\
\hline $\begin{array}{c}\text { Full PV+CHP+ } \\
\text { 1100xBatt }\end{array}$ & $1784 \mathrm{~K}$ & 1114 & $408 \mathrm{~K}$ & 24419.4 & 59.85 \\
\hline $\begin{array}{c}\text { Seasonal Ops with } \\
\text { 20xBatt }\end{array}$ & $1784 \mathrm{~K}$ & 1114 & $408 \mathrm{~K}$ & 1221.2 & 2.99 \\
\hline
\end{tabular}

Figure 27. Use Case 2 Economic Analysis

Although seasonal operations with sufficient battery capacity to eliminate the need for curtailment (20x the original battery capacity of $42.2 \mathrm{kWh}$ ) requires a slightly higher initial investment, it can be seen that the payback period ('break even' point) is less than all other options, with the exception of a PV only installation $(176 \mathrm{~kW}+$ $1 \mathrm{x} 42.2 \mathrm{kWh}$ batt). However, since the annual savings with the PV only installation are just over half of the potential savings for seasonal operation $(+20 \times 42.2$ $\mathrm{kWh}$ batt), the seasonal approach was determined to be the most favorable.

\subsection{Use Case 3 Simulation}

Use Case 3 represents grid-connected operation of the micro-grid (including the diesel generator, CHP generator, PVs, battery ESS, and a connection to the Manitoba electric grid). The definition of net power $\left(P_{n e t}\right)$ is the same as in Use Case 2. Note that for these simulations, the original battery size $(42.2 \mathrm{kWh})$ was used as the grid connection will provide an alternate load (for $P_{\text {net }} \geq 0$ ) and source (for $P_{\text {net }} \leq 0$ ) for the microgrid. In both cases, the grid will only engage once available battery capacity (charge or discharge) has been used.

To start, Day 0 (winter) and Day 220 (summer) were re-evaluated as an initial verification of the rule based simulation in grid-connected mode. The results are shown in Figure 28 and summarized in Table 11 and Table 12. For Day 0, the diesel generator operates at the minimum loading level $(96 \mathrm{~kW})$ and the CHP generator provides continuous power at $40 \mathrm{~kW}$. The battery begins at $50 \%$ SOC and can be seen to discharge power at the start of the simulation. As soon as battery power is depleted, the grid comes online, providing any additional power needed to satisfy demand. For Day 220 , the system behavior is the same; however, where a surplus power is available, power is sold back to the grid. This can also be seen in the negative price for 'Grid Cost' in Table 12, where more power is sold to the grid than purchased.
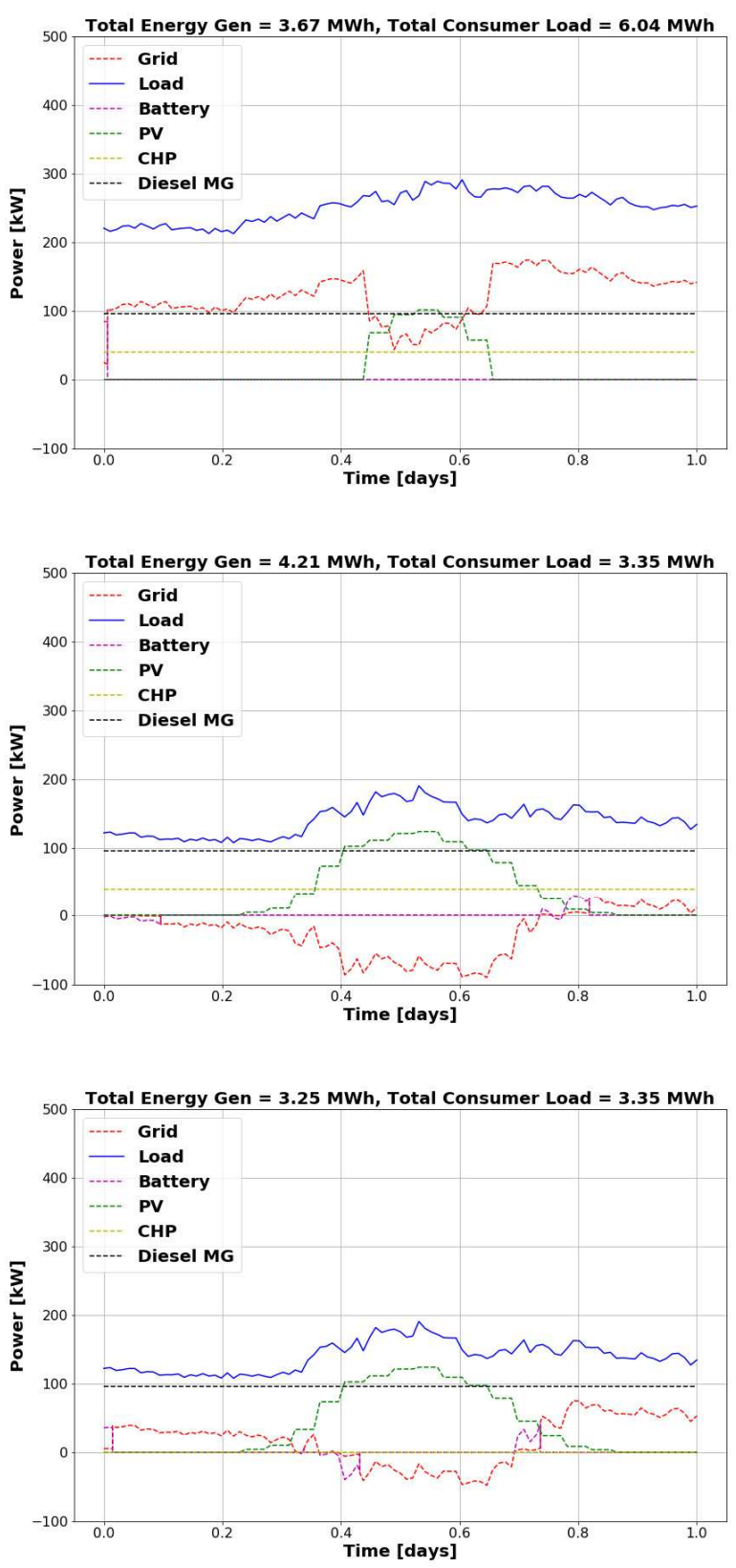

Figure 28. Power Gen. - Use Case 3 - Day 0 (top), Day 220 with CHP (middle), Day 220 without CHP (bottom)

Table 11. Sim. Use Case 1, 2 \& 3 Comparison - Day 0

\begin{tabular}{|l|c|c|c|}
\hline Description & $\begin{array}{c}\text { Use } \\
\text { Case 1 }\end{array}$ & $\begin{array}{c}\text { Use } \\
\text { Case 2 }\end{array}$ & $\begin{array}{c}\text { Use } \\
\text { Case 3 }\end{array}$ \\
\hline Total Generated / & $6.8 /$ & $6.6 /$ & $3.7 /$ \\
Load (MWh) & 6.04 & 6.04 & 6.04 \\
\hline Diesel Fuel (L) & $2.16 \mathrm{~K}$ & $1.68 \mathrm{~K}$ & $0.70 \mathrm{~K}$ \\
\hline CHP Fuel (kg) & -- & $0.96 \mathrm{~K}$ & $0.96 \mathrm{~K}$ \\
\hline $\mathrm{CO}_{2 \mathrm{e}}$ (tons) & 5.85 & 4.53 & 1.90 \\
\hline Grid Cost (CDN\$) & -- & -- & 380.00 \\
\hline Total Cost (CDN\$) & $7.74 \mathrm{~K}$ & $6.8 \mathrm{~K}$ & $3.79 \mathrm{~K}$ \\
\hline
\end{tabular}


Table 12. Sim. Use Case 1,2 \& 3 Comparison - Day 220 with CHP (3a), without CHP $(1,2$, and 3b)

\begin{tabular}{|l|c|c|c|c|}
\hline Description & $\begin{array}{c}\text { Use } \\
\text { Case 1 }\end{array}$ & $\begin{array}{c}\text { Use } \\
\text { Case 2 }\end{array}$ & $\begin{array}{c}\text { Use } \\
\text { Case 3a }\end{array}$ & $\begin{array}{c}\text { Use } \\
\text { Case 3b }\end{array}$ \\
\hline $\begin{array}{l}\text { Total Gen. / } \\
\text { Load (MWh) }\end{array}$ & $\begin{array}{c}3.71 / \\
3.35\end{array}$ & $\begin{array}{c}3.65 / \\
3.35\end{array}$ & $\begin{array}{c}4.21 / \\
3.35\end{array}$ & $\begin{array}{c}3.25 / \\
3.35\end{array}$ \\
\hline $\begin{array}{l}\text { Diesel Fuel } \\
\text { (L) }\end{array}$ & $1.17 \mathrm{~K}$ & $0.89 \mathrm{~K}$ & 0.70 & 0.70 \\
\hline $\begin{array}{l}\text { CHP Fuel } \\
\text { (kg) }\end{array}$ & -- & -- & 0.96 & -- \\
\hline CO $2 \mathrm{e}$ (tons) $^{\text {GHid Cost }}$ & 3.17 & 2.41 & 1.90 & 1.90 \\
\hline $\begin{array}{l}\text { Grid } \\
\text { CDN\$) }\end{array}$ & -- & -- & -10.70 & 70.20 \\
\hline $\begin{array}{l}\text { Total Cost } \\
\text { (CDN\$) }\end{array}$ & $4.29 \mathrm{~K}$ & $3.32 \mathrm{~K}$ & $3.40 \mathrm{~K}$ & $2.73 \mathrm{~K}$ \\
\hline
\end{tabular}

Because the cost of producing power using the CHP generator is higher than the purchase cost of electricity from the grid, an additional simulation was run for Day 220 without CHP ('Use Case 3b' in Table 12). This seasonal approach once again proves to be the best option for reducing cost, diesel fuel consumption, and $\mathrm{CO}_{2 \mathrm{e}}$ emissions. Although the battery plays a minor role due to its limited capacity, it could play a very important role in maintaining power quality or providing a buffer through various transient conditions including a switch between island and grid-connected modes. Sizing the battery for these conditions, however, is outside of the scope of this study.

The final assessment for Use Case 3 looks at the economic merits of different operating strategies for this configuration (see Figure 29). For the purposes of comparison, diesel-only (Use Case 1) and the best case from Use Case 2 (seasonal operations with 20xbatt) were included in the table. For Use Case 3, the system was operated using a seasonal approach (CHP offline during days 50-300) and fully curtailed (no CHP power for the full year). As expected, the grid greatly improves operational savings overall; however, due to the high initial investment, it will take much longer to recoup costs. In the case of full CHP curtailment (no CHP), higher savings can be realized as the cost of CHP power is higher than the cost to buy it from the grid.

\begin{tabular}{|c|c|c|c|c|c|}
\cline { 2 - 6 } \multicolumn{1}{c|}{} & $\begin{array}{c}\text { Operating Cost } \\
(000 ' s \text { SCDN) }\end{array}$ & $\begin{array}{c}\text { CO2e } \\
\text { Emissions } \\
\text { (tons) }\end{array}$ & $\begin{array}{c}\text { Annual Sarings } \\
(000 \text { 's SCDN) }\end{array}$ & $\begin{array}{c}\text { Installation } \\
(000 \text { 's SCDN) }\end{array}$ & $\begin{array}{c}\text { Break- } \\
\text { even (yrs) }\end{array}$ \\
\hline Diesel Only & $2192 \mathrm{~K}$ & 1644 & 0 & 0 & 0 \\
\hline $\begin{array}{c}\text { Use Case 2 } \\
\text { Seasonal Ops with } \\
\text { 20xBatt }\end{array}$ & $1784 \mathrm{~K}$ & 1114 & $408 \mathrm{~K}$ & 1221.2 & 2.99 \\
\hline $\begin{array}{c}\text { Use Case 3 } \\
\text { Seasonal Ops with } \\
\text { Grid }\end{array}$ & $1098 \mathrm{~K}$ & 696 & $1094 \mathrm{~K}$ & $\begin{array}{c}\text { Grid Install } \\
\text { Cost + } \\
813.1 \mathrm{~K}\end{array}$ & 22.5 \\
\hline $\begin{array}{c}\text { Use Case 3 Full } \\
\text { Curtailment with } \\
\text { Grid }\end{array}$ & $1083 \mathrm{~K}$ & 696 & $1109 \mathrm{~K}$ & $\begin{array}{c}\text { Grid Install } \\
\text { Cost + } \\
523.1 \mathrm{~K}\end{array}$ & 22.5 \\
\hline
\end{tabular}

Figure 29. Use Case 3 Economic Analysis

Note that the breakeven value of 22.50 years for the grid-connected case was computed as the installation cost $(\$ 900 \mathrm{M})$ divided by diesel savings across multiple Nunavut communities (\$40M) (Konstantinos, 2016).

\subsection{Use Case 3 Optimization}

In addition to the rule-based simulation that has been used up to this point, optimization tools are also available for the Modelon Microgrid library using the Optimica Compiler Toolkit. Although computing resources were a limiting factor, short 1 day optimizations were run to demonstrate the capability of these tools in supporting additional analyses.

The first optimization performed looked to minimize micro-grid operational costs for Use Case 3 (in gridconnected mode). This use case was selected so that the state of all components in the full integrated system model would be included in the optimization. For initialization, specific parameters were set to known optimal values to reduce the time required for the optimization to converge (starting values for CHP and diesel generators were set to $0 \mathrm{~kW}$ and $96 \mathrm{~kW}$, respectively, with battery $\mathrm{SOC}=20 \%$ ). An optimization was then performed for Day 0 and Day 220 to support comparison with the results previously obtained.

Note that for the optimizations, the rules defined for the rule-based simulations do not apply. Instead, the optimization seeks to minimize a pre-defined objective function while respecting specific constraints. For this initial cost optimization, the objective function and constraints are shown below:

$$
\begin{gathered}
\int_{t_{i}}^{t_{f}} d(\text { total cost }(t))+\left(d\left(P_{\text {batt }}\right)^{2}+d\left(P_{\text {diesel }}\right)^{2}+d\left(P_{C H P}\right)^{2}\right) d t \\
\text { total cost }(t)=\text { cost }_{\text {grid }}(t)+\operatorname{cost}_{\text {diesel }}(t)+\operatorname{cost}_{C H P}(t) \\
P_{\text {batt }}: \text { Battery Power } \\
P_{\text {diesel }}: \text { Diesel Power } \\
P_{\text {CHP }}: \text { CHP Power } \\
P_{\text {diesel }} \geq 96 \mathrm{kWh} \text { (min loading) }
\end{gathered}
$$

Each squared term was included to minimize abrupt changes in these control parameters during the optimization. The results are shown in Figure 30.

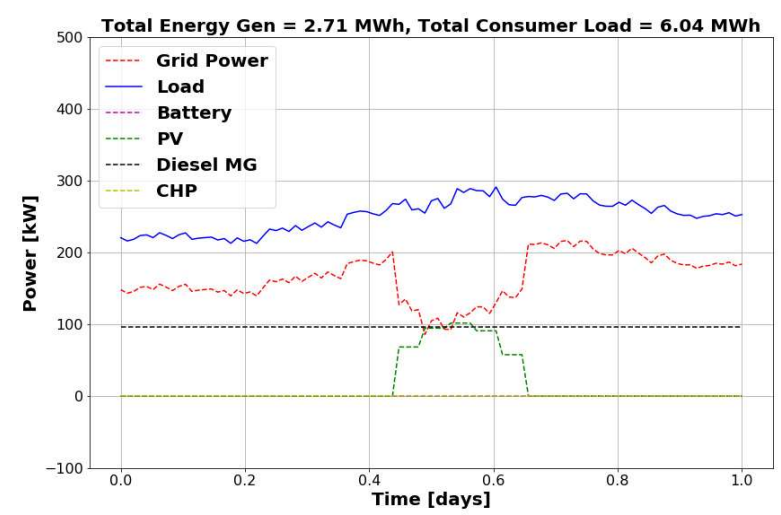

Figure 30. Use Case 3 Optimization - Day 0

With the rule-based simulation, multiple runs were required to evaluate different operational strategies in order to identify an 'optimal' operating approach; with the optimization, the results directly converged on the 
optimal solution without the approach being pre-defined (i.e., the operating condition for grid-connected mode where $\mathrm{CHP}=0 \mathrm{~kW}$ and diesel $=96 \mathrm{~kW}$, with grid power making up the remaining power required).

The results for the cost optimization performed on Day 220 directly match the 'optimal' results shown in Figure 28 (lower plot) with the exception of the battery. In the rule-based simulation, the battery charged and discharged more rapidly (Figure 31 - bottom). With the optimization, the battery charged and discharged more gradually, having an almost imperceptible impact on the overall power balance (Figure 31 - middle and top). Since batteries prefer to be charged and discharged slowly, with costs, fuel consumption, and emissions remaining equal, the optimized approach is preferable with respect to maintaining battery health and having the potential to extend battery life.
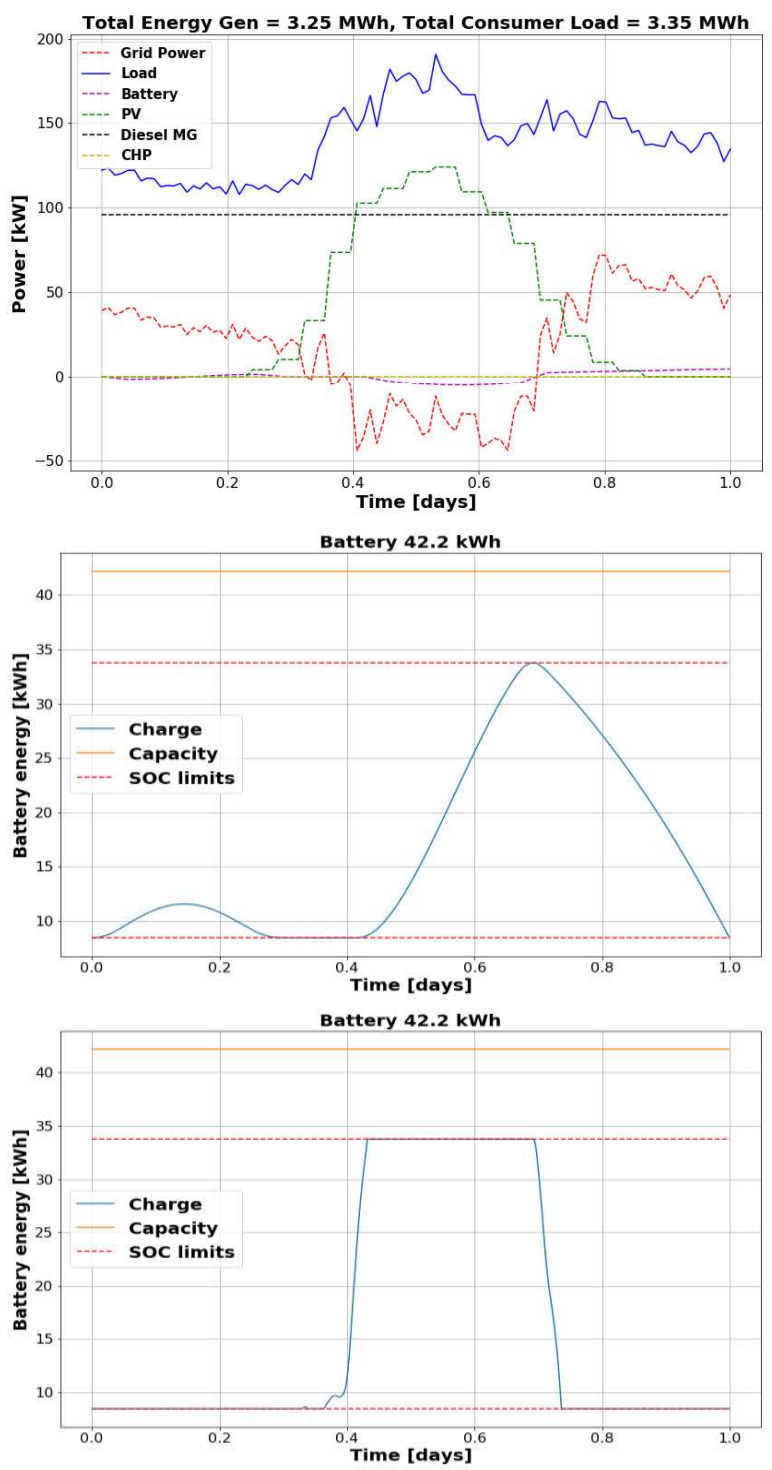

Figure 31. Use Case 3 - Optimization - Day 220 - Power Generation (top), Optimization Battery (middle), RuleBased Simulation Battery (bottom).

\section{Conclusions}

The introduction of renewable energy sources into micro-grid applications offers the potential to reduce operating costs, reliance on diesel, and the environmental impact of micro-grids powered solely by diesel power plants. Having the ability to optimize system design, evaluate performance, and quantify the potential economic benefits of micro-grids that include renewables will be essential to moving these technologies forward. By using the Microgrid Modelica library models, many high-level analyses and optimizations can be performed to answer initial questions on equipment sizing, energy balance, fuel usage, GHG emissions, and costs. Combined with the physical Micro-Grid Testing and Training Facility, this simulation platform will help to support the future integration of renewable energy generation and storage technologies into a variety of micro-grid applications.

\subsection{Future Work}

Plans for future work include integrating higher fidelity models from Modelon's Electric Power Modelica library into a comparable model framework to analyze the micro-grid's response to transient conditions on both the supply and demand side with respect to performance, stability, and reliability (e.g., analyzing stability during switching from grid connected to island mode, system performance and limitations during rapid demand changes, etc.). The Microgrid Library used for this work will be integrated into Modelon's Thermal Power Library (Modelon, 2019) and available for simulation and optimization analyses on the simulation platform Modelon Impact (Modelon, 2020).

\section{Acknowledgements}

The authors would like to express their sincere thanks to Spencer Sumanik (Yukon College) and ATCO Electric Yukon for providing access to the load data used in this study. The authors would also like to thank Johan Windahl and Hakan Runvik for their part in the development of the Modelon Microgrid modeling / simulation platform.

\section{References}

Susanne Ackeby, Jonas Tjader, Caroline Bastholm. "The role of interaction of microgrids and centralized grids in development modern power systems." $8^{\text {th }}$ Southern Africa Regional Conference, IEA-ISGAN, Nov 14-17, 2017

Johan Åkesson. "Optimica-an extension of Modelica supporting dynamic optimization." In 6th International Modelica Conference 2008. Modelica Association, March 2008

ATCO Electric Yukon (2015). Old Crow Load data for 2015 (full year), sampled in 15 minutes intervals. 
BCME (2014). British Columbia Ministry of Environment, "B.C. Best Practices Methodology for Quantifying Greenhouse Gas Emissions". November 2014. https://www.toolkit.bc.ca/sites/default/files/2014 best pra ctices methodology for quantifying greenhouse gas em issions $\% 20 \% 281 \% 29 . \mathrm{pdf}$

Caterpillar (2010). "C4.4 Generator Set Electric Power." LEHE0867-00 CAN. www.Cat-ElectricPower.com

CBM (2019). Canadian Biomass Magazine - Canadian

Biomass Pellet Map 2019.

https://www.canadianbiomassmagazine.ca/wpcontent/uploads/2019/05/CBM-PELLET-MAP2019 HR.pdf

CRA (2019). Canadian Good and Services Tax (GST) Rates. https://www.canada.ca/en/revenueagency/services/tax/businesses/topics/gst-hstbusinesses/charge-collect-which-rate/calculator.html\#rt

Indrajit Das, Claudio Canizares. "Renewable Energy Deployment in Canadian Arctic. Phase I: Pre-Feasibility Studies and Community Engagement Report for Nunavut." Waterloo Institute for Sustainable Energy (WISE) for World Wildlife Fund (WWF), 2016. http://awsassets.wwf.ca/downloads/summary and prefeasi bility report.pdf

Indrajit Das, Claudio Canizares. "Feasibility Studies of Variable Speed Generators for Canadian Arctic Communities". Waterloo Institute for Sustainable Energy (WISE) for Innovus Power, 2017.

EV Shop (2019). https://evshop.eu/en/batteries/117-5300whbmw-i3-battery-module-45v-120ah-nominal.html

GOC (2019). Government of Canada (GOC) Minimum

Wage Survey in Nunavut.

https://www.gov.nu.ca/justice/news/minimum-wagesurvey

Chelsea Harvey, Niina Heikkinen. "Congress Says Biomass is Carbon Neutral but Scientists Disagree". Scientific American E\&E News Environment, March 23, 2018.

Hydro Manitoba (2021). Generating Your Own Electricity https://www.hydro.mb.ca/accounts_and_services/generatin g_your own electricity/; Commercial Large Service Rates https://www.hydro.mb.ca/accounts and services/rates/co mmercial_rates/

ITP (2019). Renewable Energy in Nunavut Scoping Analysis, IT Power Group, Sept 2019. https://d2akr19rvxl3z3.cloudfront.net/downloads/re in nu navut scoping analysis final report variation v1 4.pdf

Konstantinos Karanasios, Paul Parker. "Recent Developments in Renewable Energy in Remote Aboriginal Communities, Nunavut, Canada". Papers in Canadian Economic Development - University of Waterloo. Vol. 16, pp 54-64, 2016, DOI: http://dx.doi.org/10.15353/pced.v16i0

Susan Kraemer, Solar Paces. Oct 11, 2017. http://www.solarpaces.org/csp-competes-with-natural-gasnot-pv/

NREL (2017). National Renewable Energy Laboratory NREL/TP-6A20- 68925. U.S. Solar Photovoltaic System Cost Benchmark: Q1 2017. Golden, CO. https:/www.nrel.gov/docs/fy17osti/68925.pdf
NREL (2019). Ver 6.1.3. National Renewable Energy Laboratory PV Watts Calculator - Solar Resource Data https://pvwatts.nrel.gov/pvwatts.php

NREL (2019a). National Renewable Energy Laboratory NREL/TP-6A20-73222. Cost Projections for Utility-Scale Battery Storage. Golden, CO.

https://www.nrel.gov/docs/fy19osti/73222.pdf

NRC (2019). National Research Council Canada (NRC), "Microgrid testing and training facility." https://nrc.canada.ca/en/research-development/nrcfacilities/microgrid-testing-training-facility

Natural Resources Canada (NRCan 1). "Towards Renewable Energy Integration in Remote Communities: A Summary of Electric Reliability Considerations." Energy and Mines Minsters' Conference, pp 1-23, Aug 2018. ISBN 978-0660-27560-4

Natural Resources Canada (NRCan 2). "Photovoltaic and solar resource maps". Mar 202017

https://www.nrcan.gc.ca/18366

NEAS (2018). Nunavut Eastern Arctic Shipping (NEAS) Inc. Sealift Rates for 2018 Season Nunavut (from Valleyfield, QC), March 30, 2018. https://neas.ca/wp-content/uploads/freight_nunavut.pdf

Nunavut Power. "Plant Status Report - Whale Cove 615, April 2001

https://web.archive.org/web/20040907175010/http://www. nunavutpower.com/communities/whalecove.html

Modelon (2019). Electric Power Library

https://www.modelon.com/library/electric-power-library/

Modelon (2019). Thermal Power Library https://www.modelon.com/library/thermal-power-library/

Modelon (2020). Modelon Impact https://www.modelon.com/modelon-impact/

QEC (2018). Qulliq Energy Corporation 2018/19 Rate App. http://www.qec.nu.ca/sites/default/files/20182019 qec_general_rate application.pdf

Solar-Facts (2017). "Concentrating Photovoltaic Solar Panel Technology."

https://www.solar-facts.com/panels/concentratingphotovoltaic.php

Volter (2019). https://volter.fi/technology/

Johan Windahl, Hakan Runvik, Stéphane Velut. "Platform for Microgrid Design and Operation." Proceedings of the $13^{\text {th }}$ International Modelica Conference, pp 405-412, Mar 2019. DOI: $10.3384 /$ ecp 19157405

Wood (2019). Wood Pellet Pricing in Canada. https://www.woodpelletheat.ca/convenient/pellet-sources/ 